\title{
Sources of Risk to the Health of the Population, by Inhalation of PM2.5 in the Toluca Valley, Mexico
}

Raúl Venancio Díaz Godoy ( $\sim$ raul.diaz@inin.gob.mx ) Instituto Nacional de Investigaciones Nucleares https://orcid.org/0000-0002-1138-9424

Angélica Flores Ortiz

Instituto Tecnológico de Toluca: Instituto Tecnologico de Toluca

Jose López Monroy

Instituto Nacional de Investigaciones Nucleares

Jaime Moreno Alcántara

Instituto Nacional de Investigaciones Nucleares

Judith Castellanos Moguel

Universidad Autónoma Metropolitana - Xochimilco: Universidad Autonoma Metropolitana - Xochimilco

María Teresa Núñez Cardona

Universidad Autónoma Metropolitana - Xochimilco: Universidad Autonoma Metropolitana - Xochimilco

Martha Patricia Sierra Vargas

Instituto Nacional de Enfermedades Respiratorias

Octavio Gamaliel Aztatzi Aguilar

Instituto Nacional de Enfermedades Respiratorias

\section{Research Article}

Keywords: PIXE, Multivariate analysis, Source, Emission, Risk, Mexico, ZMVT

Posted Date: September 8th, 2021

DOl: https://doi.org/10.21203/rs.3.rs-633108/v1

License: (c) (i) This work is licensed under a Creative Commons Attribution 4.0 International License.

Read Full License 


\title{
Sources of Risk to the Health of the Population, by Inhalation of PM2.5 in the Toluca Valley, Mexico
}

\section{Fuentes de riesgo a la salud de la población, por inhalación de $\mathbf{P M}_{2.5}$ en el Valle de Toluca, México}

\author{
Raúl Venancio Díaz-Godoy ${ }^{*}$, Angélica Flores-Ortiz², José López-Monroy, Jaime Moreno- \\ Alcántara ${ }^{1}$, Judith Castellanos-Mogue/3, María Teresa Núñez-Cardona ${ }^{3}$, Martha Patricia \\ Sierra-Vargas ${ }^{4}$, Octavio Gamaliel Aztatzi-Aguilar ${ }^{5}$
}

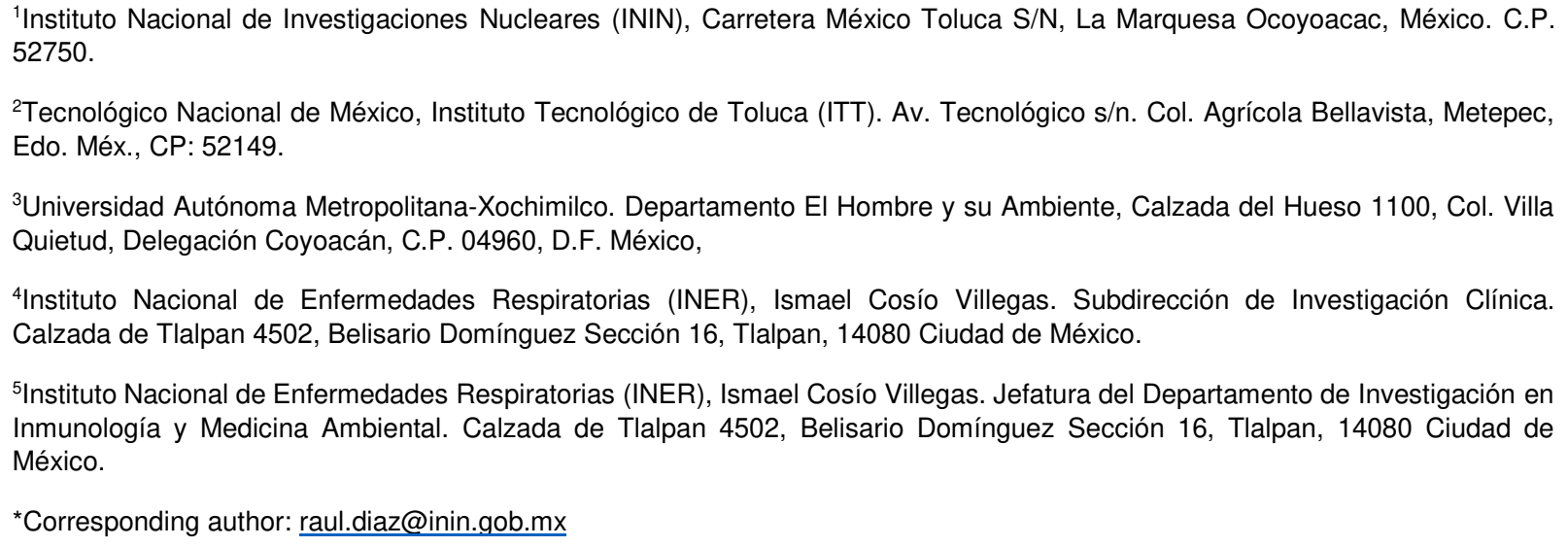

\section{Abstract:}

Introduction: $\mathrm{PM}_{2.5}$ air pollution causes death and morbidity in populations, 4.2 million premature deaths have been reported worldwide per year and can cause cardiovascular, respiratory, cancer, among other diseases. As a result, it is important to know the sources that produce them. Objective: Determine the possible Sources of Risk (SR) to health, by inhalation of Elemental Chemical Composition (EQC) obtained from $\mathrm{PM}_{2.5}$ samples in the Toluca Valley (TV). Method: Sampling was carried out (26/11/16-14/03/18) in San Mateo Atenco, Ceboruco, Nueva Oxtotitlán, San Lorenzo Tepaltitlán, Zinacantepec and San Cristóbal Huichochitlán, using medium volume equipment every six days for 24 hours. It was calculated: gravimetry, analysis by atomic technique PIXE (Proton Induced XRay Emission) to obtain the EQC. The emission sources were determined with multivariate analysis, the elemental risk for three sensitive classes of the population and their possible sources of risk. Results: The SRs determined: Dust-Soil, Industry, Hydrocarbons, Vehicle, Burn-Fuels, Fine Gravimetric Mass, Coal burning, Metallurgy and Sulphates. Discussion: The SRs with the highest values, for sensitive populations, were Industry and Dust-Soil, this as a consequence of the large number of existing industries that produce EQC. Conclusion: The risks of inhalation of EQC present in $\mathrm{PM}_{2.5}$ for sampling sites were high, because of this there is a high probability of contracting some diseases that can be caused by EQC. The risk determined for sources in the ZMTV, to date, does not exist in similar research in the literature.

Keywords: PIXE; Multivariate analysis, Source; Emission; Risk; Mexico; ZMVT

\section{Introduction}

In recent years, environmental problems such as air pollution have been growing steadily and the population has become aware of the current risks. It is estimated that environmental air pollution, both in cities and rural areas, was the cause of 4.2 million premature deaths worldwide per year; this mortality has been associated with exposure to $\mathrm{PM}_{2.5}$ particles (particles with aerodynamic diameter less than or equal to $2.5 \mu \mathrm{m}$ ), which are related to the development of cardiovascular diseases, 
respiratory diseases and cancer (WHO 2018).

In our country, the General Law of Ecological Balance and Environmental Protection, in its latest reform published DOF 18-01-2021, defines pollution as the presence in the environment of one or more pollutants or any combination of them that causes ecological imbalance and environmental contingency as a risk situation, derived from human activities or natural phenomena, which may endanger the integrity of one or more ecosystems (DOF 2021).

55 The NOM (Norma Oficial Mexicana) NOM-025-SSA1-2014, referring to environmental health, assigns permissible limit values for the Fine Gravimetric Mass (MGF) of $\mathrm{PM}_{2.5}$ in ambient air, for purposes of protecting the health of the most vulnerable population and establishes reference values of $45 \mu \mathrm{g} / \mathrm{m}^{3}$, as a 24-hour average and $12 \mu \mathrm{g} / \mathrm{m}^{3}$, as an annual average (SEGOB 2014). The National Environmental and Natural Resources Information System (SNIARN 2018) reported that the most severe case of air pollution with these particles occurred in the ZMVT, in 2016, where the annual concentration recorded was $43 \mu \mathrm{g} / \mathrm{m}^{3}$, that is, more than three times the allowed annual value.

62

The volume and characteristics of pollutants emitted into the atmosphere, both locally and regionally, determine the air quality in a particular area. However, climatic and geographic characteristics also influence the concentrations and permanence of pollutants in the air, to which populations are exposed (SNIARN 2018).

66

67

68

69

70

In the search to control emissions of pollutants in the atmosphere, which is reflected in the impact on population health by affecting chronic diseases due to poor air quality, it is necessary to perform an analysis of emission sources to identify the contribution of pollutants. Emission sources are grouped based on the type of origin (SEMARNAT 2016): stationary sources (industries), mobile sources (gasoline or diesel motor vehicles), area sources (stores, services, homes) and natural sources (soil erosion and biogenic emissions, among others).

The ZMVT is the second most important conurbation in the State of Mexico after the Metropolitan Zone of the Cuautitlán-Texcoco Valley. It is considered one of the most important towns in the central region of Mexico. It is of great industrial, commercial and service importance. Around 2,347,692 inhabitants live in this metropolis (COESPO 2019). Currently this urbe grew from 14 municipalities (2005) to 22 municipalities (2021) and consequently resulted in an increase in the demand for public services, transportation and housing. In most cases, the main source of energy, after electricity, is the combustion of fossil fuels. In addition to combustion, there are other activities that generate emissions into the atmosphere, such as the use of solvents, paint application, street paving and asphalting, fuel storage and distribution, and even some natural phenomena such as soil erosion and plant metabolism (SMAGEM 2007).

82 The Management Program to Improve Air Quality in the State of Mexico (ProAire 2018), conducted emissions inventories, including sources that emit $\mathrm{PM}_{2.5}$. Table 1 presents emissions data for different types of sources.

85

86

Table 1. Inventory of $\mathrm{PM}_{2.5}$ emissions in the ZMVT, from 2016 (ProAire 2018)

\begin{tabular}{|c|c|}
\hline \multicolumn{2}{|c|}{ PM $_{2.5}$ Emission Sources } \\
\hline Source Type & Tons / year \\
\hline $\begin{array}{c}\text { Stationary } \\
\text { sources }\end{array}$ & 442 \\
\hline Area sources & 4,271 \\
\hline Mobile sources & 502 \\
\hline Total & $\mathbf{5 , 2 1 6}$ \\
\hline
\end{tabular}

Table 1 shows that there are high levels of emissions, which represent a high risk to the health of the 
89

90

91

92

93

94

95

96

97

108

109

110

111

112

113

114

115

116

117

\section{8}

119

population. Measuring exposure to air pollution and the numerous environmental factors that influence it is complex because there are no adequate health information and monitoring systems to assess the magnitude and severity of the risks. With the objective of contributing to the evaluation of health risk in this study, the CQE of $\mathrm{PM}_{2.5}$ was determined, the health risk due to inhalation of the elements that constitute its composition was calculated in the sensitive age groups of the population, and the health risk caused by each type of source. It should be noted that the CQE is not routinely determined by the country's atmospheric monitoring networks and therefore neither is the health risk estimated for each element, nor the risk caused by each source.

\section{Materials and Methods}

\section{Study site selection}

For the selection of the monitoring site, the USEPA reference codes were considered (USEPA, 2012). Within which the following criteria were considered to locate the monitoring site:

1. Be representative of the area in which they are located.

2. Provide data comparable with other stations.

3. Be useful for at least the entire time period of the study.

4. Be permanently accessible.

5. Have reliable electrical power.

6. Be conditioned to withstand extreme temperature conditions.

7. Free of trees and buildings (recommended free radius of $10 \mathrm{~m}$. around the sampling site).

8. $20 \mathrm{~m}$. distance from the sampling site to industrial, commercial or mobile emissions sources is recommended.

9. Sampling height of 2 to 15 meters.

Under these criteria, the following study sites were selected: San Mateo Atenco (SM), Ceboruco (CB), Nueva Oxtotitlán (NO), San Lorenzo Tepaltitlán (SL), Zinacantepec (ZN) and San Cristóbal Huichochitlán (SC).

\section{Sampling campaign}

The sampling campaign was conducted under the following characteristics: the sample collection period was from November 26, 2016 to March 14, 2018 with a sampling frequency of every six days, for 24 hours each sample. Filters of $47 \mathrm{~mm}$ diameter and pore size of 0.4 micrometers (Nucleopore, \# WHA111137) were used for $\mathrm{PM}_{2.5}$. The sampling method was active, using low volume equipment model ECHO PM TCR TECORA (flow $16 \mathrm{l} / \mathrm{min}$ ) and OMNI BGI (flow $7 \mathrm{l} / \mathrm{min}$ ).

\section{Fine Gravimetric Mass Analysis}

A high-precision analytical balance, Mettler Toledo M5 series No. 11441 (Mettler 2008), was required to determine the amount of matter deposited on the filters. Calculations of the $\mathrm{PM}_{2.5}$ concentration in ambient air were performed using the following expression:

\section{Where:}

$$
M G F=\frac{m f-m i}{V t}=\mu g / m^{3}
$$

MGF: Concentration of $\mathrm{PM}_{2.5}$ in air

mf: Final mass in the filter $(\mu \mathrm{g})$ 
mi: Initial mass in the filter $(\mu \mathrm{g})$

Vt: Total volume $\left(\mathrm{m}^{3}\right)$

\section{Elemental Chemical Composition Analysis}

138

139

140

141

142

143

144

145

146

147

148

149

150

151

152

The Chemical Elemental Composition (CQE) was determined using the atomic technique called PIXE. The experimental characteristics were:

a) Calibration of the PIXE system was performed using high purity MicromatterTM brand standards, (Al, S, K, Ca Ti, V, Cr, Mn, Fe, Co, Ni Cu Zn, Br and Pb), using the same experimentalconditions with which the samples were irradiated.

b) 12 MV Van de Graaff Tandem Accelerator (Figure 1).

c) Ion: Proton

d) Beam energy (E): $2.5 \mathrm{MeV}$

e) Beam current (I): $10.0 \mathrm{nA}$

f) Charge on filter $(Q): 4.0 \mu \mathrm{C}$

g) Ge-Li detector with a resolution of $180 \mathrm{eV}$

h) Software for X-Ray Characteristic Spectra analysis: GUPIXWIN

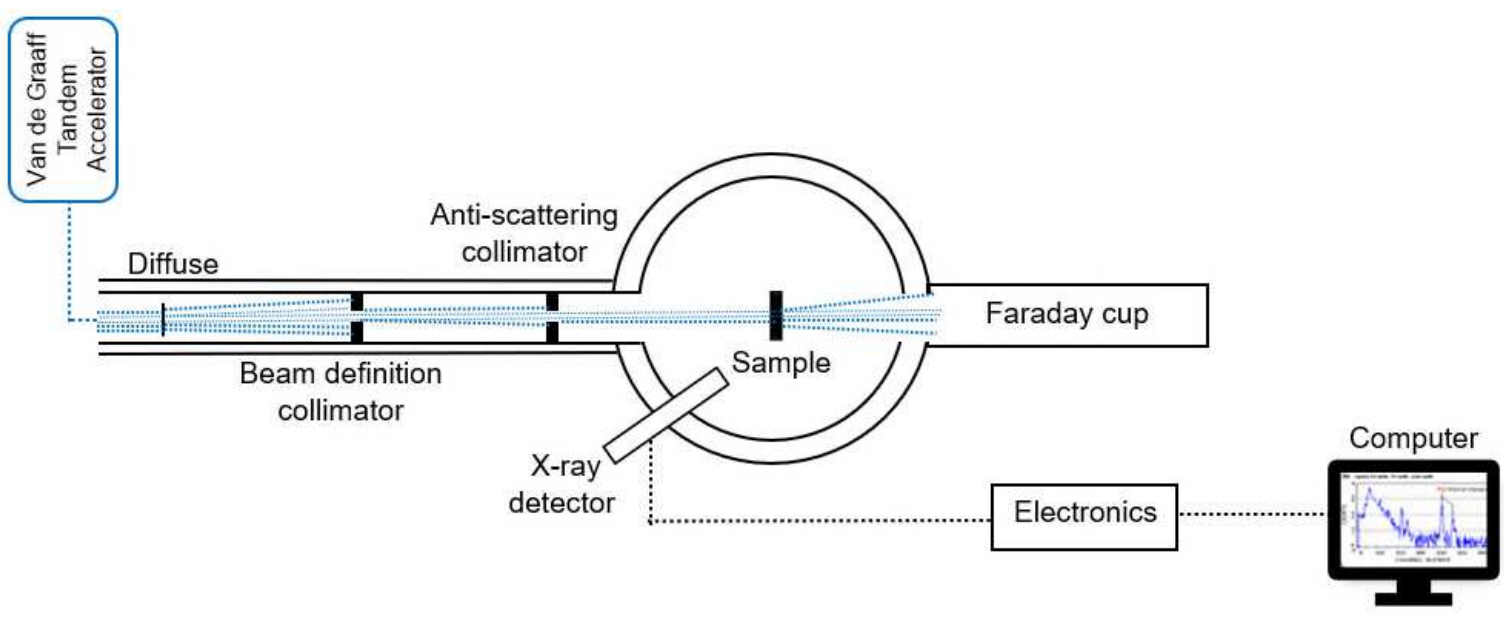

Figure 1. Experimental set-up at the ININ Van de Graaff Tandem Accelerator

From the characteristic X-Ray spectrum generated and the adjustments made with the GUPIXWIN software, the X-Ray yield (Nx) was calculated for each of the elements present in the sample.

The elemental chemical concentration $c(Z)$ present in the sample is proportional to the number of detected X-rays ( $\mathrm{Nx}$ ) and inversely proportional to the charge supplied to the sample, i.e:

$$
c(Z)=\left[N x /\left(Y_{R} Q\right)\right] \ldots(1)
$$

Where:

$\mathrm{Q}=$ Is the load supplied to the sample during irradiation. 
$\mathrm{YR}=$ is the response factor involving physical fundamentals of the experimental setup.

167 With:

This response factor (YR) is obtained for each element, with the calibration of the system (Folkmann 1975), so using equations 1 and 2 the expression 3 is obtained, with which it is possible to calculate the concentration of the elemental chemical composition of the sample in $\mu \mathrm{g} / \mathrm{m}^{3}$.

Where:

$\Omega=$ Solid Angle of the detector.

$\sigma x=$ Shock cross section for X-Ray production.

$\xi=$ Efficiency of the detector.

$\mathrm{T}=$ Transmittance

$q=$ Charge due to the incident particle.

186

\section{Determination of emission sources}

For the identification of possible emission sources in this research, statistical tools such as multivariate techniques were used.

The sequence followed for the identification was carried out according to Jhonson and Wichern (1992) and consisted of the following steps:

1. Calculate the correlation matrix between variables. The correlation matrix was calculated using SPSS version 22 software.

2. Apply extraction method. With the same software, the extraction of factors was performed using the rectangular components method. This analysis considers $n$ quantitative variables and mixes them by means of linear combinations reducing to $p<n$ variables that summarize the information facilitating its interpretation.

3. Apply transformation method. The method used to transform, to rotate the matrix, was VARIMAX established by Kaiser 1958, based on the criterion of maximizing the variance of the loadings of each component. To do this, it takes the total variance associated with the retained and unrotated components and redistributes it through the new rotated VARIMAX components. The same software was also used for this rotation.

4. Determine the number of significant factors. The most significant components were defined and selected. For this purpose, the components with the highest total variance explained (greater than $70 \%$ ) were considered.

The data handled through this sequence were subjected to statistical criteria such as the Kaiser-MeyerOlkin (KMO) and Bartlett's test, which showed that the statistical significance of the data structure is appropriate.

\section{Elemental Chemical Composition Risk}

213 For risk calculation, it is essential to have the Exposure Dose (ED), Exposure Factors (EF) and 214 Reference Dose (RD). 


\section{Exposure Dose}

217 For the calculation of Exposure Dose, according to the sources Peña et al. (2001), CEPIS and 218 PAHO (1997), ATSDR (2018) and USEPA (2016), the elemental concentrations obtained for the 219 elements, whose reference dose was found in the literature were used: $\mathrm{S}, \mathrm{Cl}, \mathrm{Ti}, \mathrm{V}, \mathrm{Cr}, \mathrm{Mn}, \mathrm{Ni}$, $220 \mathrm{Cu}, \mathrm{Zn}$, and $\mathrm{Pb}$, obtained through the PIXE technique, as well as the exposure factors shown in 221 Table 2, taken from USEPA (1997).

Table 2. Parameters for exposure dose analysis

\begin{tabular}{|c|c|c|c|}
\hline Parameter & $\begin{array}{c}\text { Children } \\
\mathbf{2 - 6} \\
\text { years }\end{array}$ & $\begin{array}{c}\text { Children } \\
\mathbf{6 - 1 2} \\
\text { years }\end{array}$ & $\begin{array}{c}\text { Adults } \\
\mathbf{7 0} \\
\text { Years }\end{array}$ \\
\hline Average body weight (kg) & 16 & 29 & 70 \\
\hline Inhaled Air Rate (m 3 /day) & 6.0 & 11.04 & 19.92 \\
\hline Retention Rate for inhaled air & 1 & 1 & 1 \\
\hline Inhaled Air Absorption Rate & 1 & 1 & 1 \\
\hline Frequency of Exposure (days) & 365 & 365 & 365 \\
\hline Duration of the Exhibition (years) & 4 & 6 & 30 \\
\hline Average Time (days) & 1460 & 2190 & 25550 \\
\hline
\end{tabular}

224

225

226

227

228

229

230

231

232

233

234

235

236

237

238

239

240

241

242

243

244

245

The exposure dose is calculated using the expression:

$$
\text { Exposure dose }(\mathrm{mg} / \mathrm{kg} / \text { día })=\frac{C x T I x T R x F E x D E}{T P x P C}
$$

Where:

$\mathrm{C}=$ Concentration of the pollutant in the medium $\left(\mathrm{mg} / \mathrm{m}^{3}\right)$

$\mathrm{TI}=$ Inhaled Air Rate ( $\mathrm{m}^{3} /$ day)

$\mathrm{TR}=$ Retention Rate for inhaled air

$\mathrm{TA}=$ Absorption Rate of inhaled air

$\mathrm{FE}=$ Frequency of Exposure (days)

$\mathrm{DE}=$ Duration of Exposure (years)

$\mathrm{TP}=$ Averaging Time (days)

$\mathrm{PC}=$ Average Body Weight $(\mathrm{kg})$

The data obtained for the Exposure Dose for the three age groups are presented in the results section.

\section{Elemental Chemical Composition Risk Calculation}

Con la Dosis de Exposición calculada como se indica en la sección anterior y la Dosis de Referencia (DR) y/o Mínimo Nivel de Riesgo (MNR) obtenida de las referencias ATSDR (2018), EPA (2017), se calculó el riesgo elemental de las $\mathrm{PM}_{2.5}$ utilizando la siguiente expresión:

$$
\text { Risk }=\frac{\text { Exposure Dose }(\boldsymbol{m g} / \boldsymbol{k g} / \text { día })}{\text { Reference Dose }(\boldsymbol{m g} / \mathbf{k g} / \mathbf{d i ́})}
$$

or the concentration of the contaminant of the contaminant and the MNR in the expression:

$$
\text { Risk }=\frac{\text { Pollutant concentration }\left(\mathbf{m g} / \mathbf{m}^{3}\right)}{\text { Minimum Risk Level }\left(\mathbf{m g} / \mathbf{m}^{\mathbf{3}}\right)}
$$

With the two previous formulas it is concluded that values greater than or equal to 1 indicate the presence 
or existence of risk and values less than 1 indicate the non-existence of risk.

\section{Identification of risk sources}

248 In order to determine the sources of risk to health by inhalation of $\mathrm{PM}_{2.5}$, the emission sources obtained in

249 accordance with the previous section, determination of emission sources, were considered, assigning the

250 elemental risk to each of the elements present in the source. These results are presented in the 251 corresponding section.

\section{Results and discussions}

\section{Monitoring}

The monitoring was carried out in the ZMVT, which is made up of 22 municipalities, covering an area of $2,669 \mathrm{~km}^{2}$, which corresponds to $11.9 \%$ of the state territory. The average altitude of the municipalities is 2,610 meters above sea level, with a range from 2,560 to 2,740 meters above sea level. It has 2 million 347 thousand 692 inhabitants, as of 2019 (COESPO 2019). The selected sites are SM, CB, NO, SL, ZN and $\mathrm{SC}$, as shown in Figure 2.

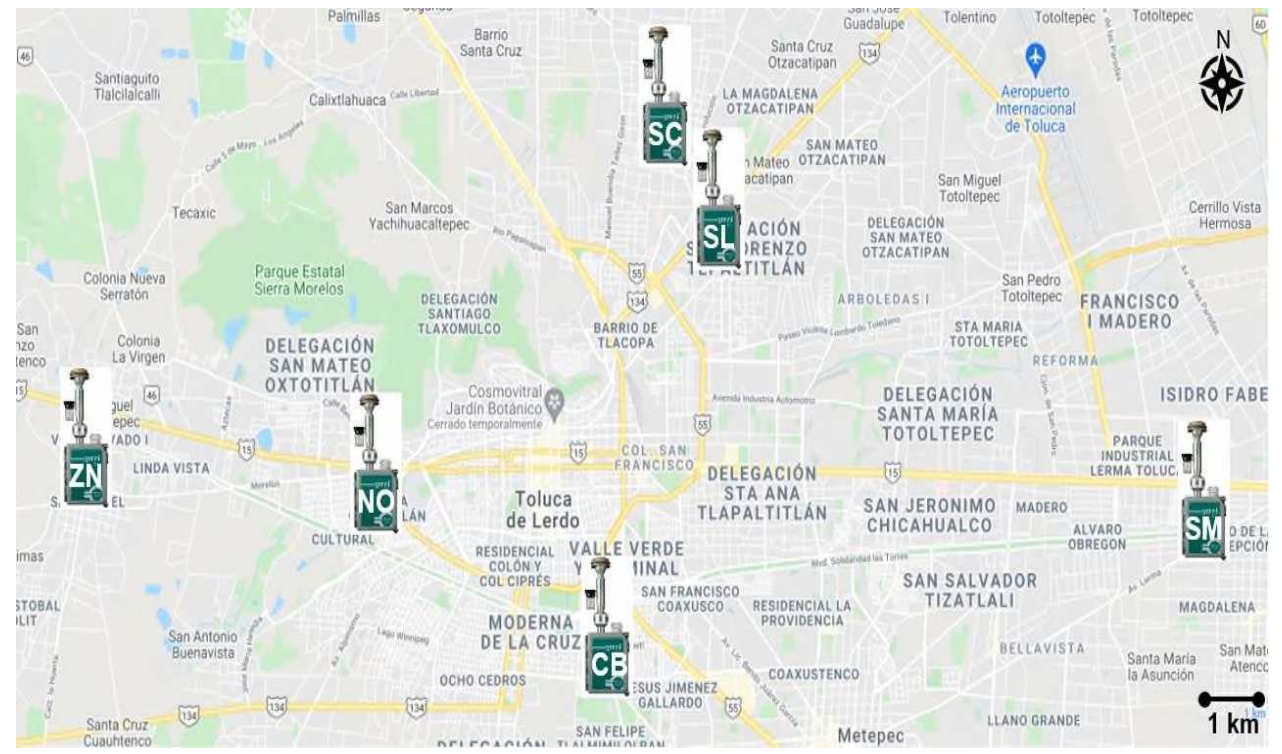

Figure 2. Selected monitoring sites in the ZMVT

Table 3 shows the coordinates of the sampling sites.

Table 3. Coordinates of the sampling sites in the ZMVT (RAMA 2021)

\begin{tabular}{|c|c|c|}
\hline Site & $\begin{array}{c}\text { Latitude } \\
\text { North }\end{array}$ & $\begin{array}{c}\text { Longitude } \\
\text { West }\end{array}$ \\
\hline $\mathrm{SM}^{\mathrm{a}}$ & $19^{\circ} 16^{\prime} 49.5^{\prime \prime}$ & $99^{\circ} 32^{\prime} 30.0^{\prime \prime}$ \\
\hline $\mathrm{CB}^{\mathrm{b}}$ & $19^{\circ} 15^{\prime} 37.1^{\prime \prime}$ & $99^{\circ} 38^{\prime} 44.6^{\prime \prime}$ \\
\hline $\mathrm{NO}^{\mathrm{c}}$ & $19^{\circ} 17^{\prime} 0.40^{\prime \prime}$ & $99^{\circ} 41^{\prime} 0.56^{\prime \prime}$ \\
\hline $\mathrm{SL}^{\mathrm{d}}$ & $19^{\circ} 19^{\prime} 2.0^{\prime \prime}$ & $99^{\circ} 37^{\prime} 18.0^{\prime \prime}$ \\
\hline $\mathrm{ZN}^{\mathrm{e}}$ & $19^{\circ} 17^{\prime} 07.5^{\prime \prime}$ & $99^{\circ} 44^{\prime} 07.1^{\prime \prime}$ \\
\hline $\mathrm{SC}^{\dagger}$ & $19^{\circ} 19^{\prime} 38.0^{\prime \prime}$ & $99^{\circ} 38^{\prime} 3.44^{\prime \prime}$ \\
\hline
\end{tabular}

asM (San Mateo Atenco), ${ }^{b} \mathrm{CB}$ (Ceboruco), ${ }^{\mathrm{c}}$ (Nueva Oxtotitlán), ${ }^{\mathrm{d}} \mathrm{SC}$ (San Cristóbal Huichochitlán), ${ }^{\mathrm{S}} \mathrm{SL}$ (San Lorenzo Tepaltitlán), ${ }^{\mathrm{f}} \mathrm{ZN}$ (Zinacantepec)

\section{Sampling campaign}

266 The sampling campaign was carried out under the characteristics described in the methodology. 


\section{Fine Gravimetric Mass Analysis}

268 Table 4 shows the results of FGM obtained from the samples collected in the selected sites of the 269 ZMVT; the maximum, average and standard deviation values are presented in units of $\mu \mathrm{g} / \mathrm{m}^{3}$.

270

Table 4. Estadísticos descriptivos de la MGF, para las muestras de la ZMVT

\begin{tabular}{|c|c|c|c|c|}
\hline $\begin{array}{c}\text { Sampling } \\
\text { Site }\end{array}$ & $\mathbf{N}$ & $\begin{array}{c}\text { Maximum } \\
\mathbf{\mu g} / \mathbf{m}^{\mathbf{3}}\end{array}$ & $\begin{array}{c}\text { Average } \\
\mathbf{\mu g} / \mathbf{m}^{\mathbf{3}}\end{array}$ & $\begin{array}{c}\text { Standard } \\
\text { Deviation }\end{array}$ \\
\hline SM & 79 & 69 & 34 & 15 \\
\hline CB & 79 & 178 & 47 & 22 \\
\hline NO & 79 & 425 & 39 & 66 \\
\hline SL & 79 & 583 & 71 & 106 \\
\hline ZN & 79 & 109 & 39 & 19 \\
\hline SC & 79 & 1070 & 75 & 149 \\
\hline
\end{tabular}

272

273

274

275

276

277

278

279

\section{0}

281

282

283

284

The maximum values, as shown in Table 4, in CB, NO, SC and SL, correspond to values obtained on December 25 and January 1, 2016-2017, repeating high values for 2017-2018, corresponding to Christmas and New Year. Days that usually have bonfires, burning tires and wood (December 25) and in addition to these, fireworks (January 1 ). The six study sites exceeded the maximum permissible limits which is $12 \mu \mathrm{g} / \mathrm{m}^{3}$ (DOF, 2014) as an annual average. The minimum value for SM exceeded it 2.8 times and the maximum value for SC exceeded it 6.2 times. These values indicate the degree of risk in the ZMVT, without considering the CQE.

\section{Elemental Chemical Composition Analysis}

This section shows the results obtained, by PIXE, for the CQE of $\mathrm{PM}_{2.5}$ in the ZMVT, Table 5 presents their descriptive statistics.

Table 5. Elemental Chemical Composition obtained by particle-induced X-ray emission

\begin{tabular}{|c|c|c|c|c|c|c|c|c|c|c|c|c|c|}
\hline \multirow[b]{2}{*}{$\mathbf{Z}$} & \multirow[b]{2}{*}{$\mathbf{N}$} & \multicolumn{2}{|c|}{ SM } & \multicolumn{2}{|c|}{ CB } & \multicolumn{2}{|c|}{ NO } & \multicolumn{2}{|c|}{ SC } & \multicolumn{2}{|c|}{$\overline{\mathrm{SL}}$} & \multicolumn{2}{|c|}{$\mathbf{Z N}$} \\
\hline & & $\overline{\mathbf{x}}$ & $\sigma$ & $\overline{\mathbf{x}}$ & $\sigma$ & $\overline{\mathbf{x}}$ & $\sigma$ & $\overline{\mathbf{x}}$ & $\sigma$ & $\overline{\mathbf{x}}$ & $\sigma$ & $\overline{\mathbf{x}}$ & $\sigma$ \\
\hline & & \multicolumn{12}{|c|}{$\mathrm{ng} / \mathrm{m}^{3}$} \\
\hline Phosphorus (P) & 79 & 790 & 3020 & 4394 & 35413 & 3172 & 17444 & 11468 & 352194 & 11811 & 67932 & 1150 & 7302 \\
\hline Sulfur (S) & 79 & 1310 & 1619 & 1164 & 1003 & 1278 & 1708 & 2412 & 8096 & 2086 & 3270 & 1210 & 1547 \\
\hline Chlorine $(\mathrm{Cl})$ & 79 & 939 & 4105 & 199 & 223 & 1133 & 5251 & 3385 & 13591 & 2331 & 10186 & 222 & 280 \\
\hline Potassium (K) & 79 & 1079 & 4634 & 521 & 681 & 1340 & 5239 & 3817 & 15407 & 2298 & 8278 & 468 & 630 \\
\hline Calcium (Ca) & 79 & 265 & 541 & 885 & 1644 & 356 & 1534 & 514 & 2231 & 1349 & 4019 & 791 & 1799 \\
\hline Titanium (Ti) & 79 & 45 & 163 & 62 & 188 & 187 & 1135 & 193 & 1274 & 409 & 2563 & 65 & 147 \\
\hline Vanadium (V) & 79 & 8 & 21 & 5 & 14 & 6 & 11 & 7 & 20 & 9 & 28 & 6 & 18 \\
\hline Chromium (Cr) & 79 & 16 & 62 & 12 & 27 & 64 & 327 & 37 & 275 & 243 & 1536 & 26 & 78 \\
\hline Manganese (Mn) & 79 & 35 & 95 & 10 & 20 & 133 & 600 & 76 & 368 & 78 & 359 & 50 & 267 \\
\hline Iron (Fe) & 79 & 302 & 615 & 542 & 506 & 293 & 999 & 445 & 1622 & 796 & 2049 & 488 & 552 \\
\hline Cobalt (Co) & 79 & 16 & 63 & 5 & 33 & 26 & 222 & 33 & 235 & 94 & 833 & 106 & 795 \\
\hline Nickel (Ni) & 79 & 89 & 305 & 109 & 578 & 169 & 957 & 148 & 1006 & 261 & 1566 & 184 & 1366 \\
\hline Copper (Cu) & 79 & 30 & 110 & 283 & 1991 & 12 & 63 & 46 & 224 & 22 & 56 & 215 & 1381 \\
\hline Zinc $(Z) n$ & 79 & 190 & 314 & 182 & 971 & 149 & 1158 & 71 & 241 & 533 & 2745 & 277 & 1175 \\
\hline Yttrium (Y) & 79 & 39 & 240 & 137 & 627 & 53 & 248 & 57 & 290 & 365 & 1240 & 309 & 1127 \\
\hline Lead $(P b)$ & 79 & 79 & 182 & 24 & 121 & 804 & 6950 & 362 & 2263 & 2300 & 19736 & 4 & 28 \\
\hline
\end{tabular}




\section{Elemental Chemical Composition Risk}

Table 6 presents the estimated risks for inhalation of $\mathrm{PM}_{2.5}$ composition. It is observed that there is an increased health risk from exposure of $\mathrm{PM}_{2.5}$ content of contracting any disease related to the elements: $\mathrm{Cl}, \mathrm{Ti}, \mathrm{Cr}, \mathrm{Mn}$ and $\mathrm{Pb}$ for the inhalation exposure route and for the sensitive classes of the population considered. These elements present a health risk by this route of entry and most of them are very high risk, for example: Chlorine for SC (children 6-12 years old), Titanium for NO (adults and children), Chromium for SL (children 6-12 years old), Manganese for NO (children 6-12 years old) and Lead for SC (adults and children). From these results it is observed that the most affected sensitive classes of the population are for adults and children 6-12 years old and the highest risk sites are SC and SL. Individually, there is no possibility of contracting any disease as a consequence of exposure to the elements $S$, $\mathrm{V}, \mathrm{Ni}, \mathrm{Cu}, \mathrm{Zn}$ and MGF, which are the elements that are presented with the lowest risk value $(<1)$, however, exposure to these elements is as a whole, therefore, we do not rule out that the individual effects may interact in synergy.

Table 6. Relationship of health risk values for CQE inhalation, present in $\mathrm{PM}_{2.5}$ in the six sites of the ZMVT

\begin{tabular}{|c|c|c|c|c|c|c|c|c|c|}
\hline \multirow{3}{*}{ Elements } & \multicolumn{3}{|c|}{ NO } & \multicolumn{3}{|c|}{$S C$} & \multicolumn{3}{|c|}{$C B$} \\
\hline & $\begin{array}{c}\text { Children } \\
2-6 \\
\text { years }\end{array}$ & $\begin{array}{c}\text { Children } \\
6-12 \\
\text { years }\end{array}$ & $\begin{array}{l}\text { Adults } \\
70 \\
\text { años }\end{array}$ & $\begin{array}{c}\text { Children } \\
2-6 \\
\text { years }\end{array}$ & $\begin{array}{c}\text { Children } \\
6-12 \\
\text { years }\end{array}$ & $\begin{array}{l}\text { Adults } \\
70 \\
\text { años }\end{array}$ & $\begin{array}{c}\text { Children } \\
2-6 \\
\text { years }\end{array}$ & $\begin{array}{c}\text { Children } \\
6-12 \\
\text { years }\end{array}$ & $\begin{array}{l}\text { Adults } \\
70 \\
\text { years }\end{array}$ \\
\hline & \multicolumn{3}{|c|}{$R=D E / D R$} & \multicolumn{3}{|c|}{$R=D E / D R$} & \multicolumn{3}{|c|}{$R=\mathrm{DE} / \mathrm{DR}$} \\
\hline $\mathbf{S}$ & 0.394 & 0.4 & 0.128 & 0.663 & 0.673 & 0.216 & 0.167 & 0.17 & 0.054 \\
\hline $\mathrm{Cl}$ & 137.004 & 139.083 & 44.557 & 363.109 & 368.618 & 118.092 & 6.11 & 6.203 & 1.987 \\
\hline $\mathrm{Ti}$ & 31.706 & 31.706 & 31.706 & 15.644 & 15.644 & 15.644 & 3.654 & 3.654 & 3.654 \\
\hline V & 0.002 & 0.002 & 0.001 & 0.004 & 0.004 & 0.001 & 0.003 & 0.003 & 0.001 \\
\hline $\mathrm{Cr}$ & 14.092 & 14.306 & 4.583 & 1.213 & 1.231 & 0.394 & 0.621 & 0.63 & 0.202 \\
\hline Mn & 73.598 & 74.715 & 23.936 & 25.914 & 26.307 & 8.428 & 1.857 & 1.885 & 0.604 \\
\hline $\mathrm{Ni}$ & 0.059 & 0.06 & 0.019 & 0.023 & 0.023 & 0.007 & 0.037 & 0.037 & 0.012 \\
\hline $\mathrm{Cu}$ & 0.002 & 0.002 & 0.002 & 0.005 & 0.005 & 0.005 & 0.027 & 0.027 & 0.027 \\
\hline Zn & 0.0003 & 0.0003 & 0.0001 & 0.001 & 0.001 & 0.0003 & 0.002 & 0.002 & 0.001 \\
\hline $\mathrm{Pb}$ & 20.316 & 20.316 & 20.316 & 106.64 & 106.64 & 106.64 & 15.181 & 15.181 & 15.181 \\
\hline MGF & 0.014 & 0.014 & 0.014 & 0.018 & 0.018 & 0.018 & 0.002 & 0.002 & 0.002 \\
\hline $\begin{array}{c}\text { Riesgo } \\
\text { Total }\end{array}$ & 277.188 & 280.604 & 125.263 & 513.233 & 519.164 & 249.445 & 27.66 & 27.794 & 21.724 \\
\hline \multirow{3}{*}{ Elements } & \multicolumn{3}{|c|}{$Z N$} & \multicolumn{3}{|c|}{$S L$} & \multicolumn{3}{|c|}{$S M$} \\
\hline & $\begin{array}{c}\text { Children } \\
2-6 \\
\text { years }\end{array}$ & $\begin{array}{c}\text { Children } \\
6-12 \\
\text { years }\end{array}$ & $\begin{array}{l}\text { Adults } \\
70 \\
\text { años }\end{array}$ & $\begin{array}{c}\text { Children } \\
2-6 \\
\text { years }\end{array}$ & $\begin{array}{c}\text { Children } \\
6-12 \\
\text { years }\end{array}$ & $\begin{array}{l}\text { Adults } \\
70 \\
\text { años }\end{array}$ & $\begin{array}{c}\text { Children } \\
2-6 \\
\text { years }\end{array}$ & $\begin{array}{c}\text { Children } \\
6-12 \\
\text { years }\end{array}$ & $\begin{array}{l}\text { Adults } \\
70 \\
\text { años }\end{array}$ \\
\hline & \multicolumn{3}{|c|}{$R=D E / D R$} & \multicolumn{3}{|c|}{$R=D E / D R$} & \multicolumn{3}{|c|}{$R=D E / D R$} \\
\hline $\mathbf{S}$ & 0.253 & 0.257 & 0.082 & 0.733 & 0.744 & 0.238 & 0.313 & 0.318 & 0.102 \\
\hline $\mathrm{Cl}$ & 4.746 & 4.818 & 1.544 & 255.297 & 259.171 & 83.029 & 88.945 & 90.295 & 28.927 \\
\hline $\mathrm{Ti}$ & 6.731 & 6.731 & 6.731 & 29.686 & 29.686 & 29.686 & 3.906 & 3.906 & 3.906 \\
\hline V & 0.002 & 0.002 & 0.001 & 0.005 & 0.005 & 0.002 & 0.005 & 0.005 & 0.002 \\
\hline $\mathrm{Cr}$ & 3.684 & 3.74 & 1.198 & 32.554 & 33.048 & 10.587 & 1.223 & 1.242 & 0.398 \\
\hline$M n$ & 16.853 & 17.109 & 5.481 & 27.455 & 27.871 & 8.929 & 8.797 & 8.93 & 2.861 \\
\hline $\mathrm{Ni}$ & 0.019 & 0.019 & 0.006 & 0.072 & 0.073 & 0.023 & 0.025 & 0.025 & 0.008 \\
\hline $\mathrm{Cu}$ & 0.029 & 0.029 & 0.029 & 0.002 & 0.002 & 0.002 & 0.007 & 0.007 & 0.007 \\
\hline $\mathrm{Zn}$ & 0.005 & 0.006 & 0.002 & 0.008 & 0.008 & 0.003 & 0.002 & 0.002 & 0.001 \\
\hline $\mathrm{Pb}$ & 1.292 & 1.292 & 1.292 & 61.119 & 61.119 & 61.119 & 17.191 & 17.191 & 17.191 \\
\hline MGF & 0.002 & 0.002 & 0.002 & 0.012 & 0.012 & 0.012 & 0.001 & 0.001 & 0.001 \\
\hline $\begin{array}{c}\text { Riesgo } \\
\text { Total }\end{array}$ & 33.617 & 34.005 & 16.368 & 406.944 & 411.74 & 193.631 & 120.415 & 121.922 & 53.403 \\
\hline
\end{tabular}


Table 7. Summary of CQE inhalation hazards in the ZMVT

\begin{tabular}{|c|c|c|c|}
\hline $\begin{array}{c}\text { (Totals) } \\
\text { Site }\end{array}$ & $\begin{array}{c}\text { Children } \\
\mathbf{2 - 6} \\
\text { years }\end{array}$ & $\begin{array}{c}\text { Children } \\
\mathbf{6 - 1 2} \\
\text { years }\end{array}$ & $\begin{array}{c}\text { Adults } \\
\mathbf{7 0} \\
\text { years }\end{array}$ \\
\hline SM & 120.41 & 121.92 & 53.40 \\
\hline CB & 27.66 & 27.79 & 21.71 \\
\hline NO & 277.17 & 280.59 & 125.25 \\
\hline SL & 406.93 & 411.73 & 193.62 \\
\hline ZN & 33.62 & 34.00 & 16.37 \\
\hline SC & 513.21 & 519.15 & 249.43 \\
\hline
\end{tabular}

\section{Determination of Emission Sources}

311 Statistical tools such as multivariate techniques were used to identify possible emission sources in this 312 investigation. Tables 8 to 13 show the results obtained.

313 Table 8 shows that the rotated matrix of the data (VARIMAX) results in three significant components, 314 which were associated with soil dust, hydrocarbons and sulfates. The principal component analysis 315 shows that these three components explain $97.4 \%$ of the variability of the data.

316 The association of the elements $\mathrm{Ca}, \mathrm{Ti}, \mathrm{Cu}, \mathrm{Mn}, \mathrm{Cr}, \mathrm{K}, \mathrm{Ni}, \mathrm{Cl}$ and $\mathrm{Fe}$, to determine the source of Soil Dust 317 are in agreement with those found by Almeida et al. (2020) in Europe and Central Asia, Alvarez and 318 Suarez (2020) in Peru and Rojas et al. (1990) in Santiago de Chile. The source of Hydrocarbons, FGM, V 319 and Zn, agreed with Banerjee et al. (2015) in India and Rojas et al. (1990). The sulfate factor composed 320 of $\mathrm{Pb}$ and $\mathrm{S}$, agreed with Rojas et al. (1990).

Table 8. Emission sources obtained for $\mathrm{PM}_{2.5}$ from SM site

\begin{tabular}{|c|c|c|c|c|c|c|}
\hline Element & Soil dust & Hydrocarbons & Sulfates & Community & $\begin{array}{c}\% \\
\text { Variance }\end{array}$ & $\begin{array}{c}\% \\
\text { Cumulative }\end{array}$ \\
\hline $\mathbf{C a}$ & 0.990 & & & 0.990 & 64.907 & 64.907 \\
\hline $\mathbf{T i}$ & 0.986 & & & 0.988 & & \\
\hline $\mathbf{C u}$ & 0.982 & & & 0.955 & & \\
\hline $\mathbf{M n}$ & 0.980 & & 0.980 & & \\
\hline $\mathbf{C r}$ & 0.978 & & 0.999 & & \\
\hline $\mathbf{K}$ & 0.977 & & & 1.000 & & \\
\hline $\mathbf{N i}$ & 0.975 & & 0.908 & & \\
\hline $\mathbf{C l}$ & 0.906 & & & 0.999 & & \\
\hline $\mathbf{F e}$ & 0.903 & & & 1.000 & & \\
\hline $\mathbf{M G F}$ & & 0.976 & & 1.000 & 18.076 & \\
\hline $\mathbf{V}$ & & -0.922 & & 1.000 & & \\
\hline $\mathbf{Z n}$ & & -0.739 & & 0.998 & & \\
\hline $\mathbf{P b}$ & & & 0.954 & 0.902 & 14.431 & \\
\hline $\mathbf{S}$ & & & 0.768 & 0.920 & & \\
\hline
\end{tabular}

Table 9, corresponding to $\mathrm{BC}$, shows the possible emission sources obtained, where it is observed that the rotated matrix of the data (VARIMAX) results in three significant components, which were associated with Soil Dust, Metallurgy and Fuel Burning. The principal component analysis shows that these three components explain $83.04 \%$ of the variability of the data. 
The elements $\mathrm{Ca}, \mathrm{Fe}, \mathrm{Ti}, \mathrm{Zn}$ and $\mathrm{Cr}$, are associated with the source Soil dust and agree with what was reported by Almeida et al. (2020) and Owoade et al. (2015). The K, Cl and MGF corresponding to the Metallurgy source agree with that reported by Owoade et al. (2015) in Nigeria. The S and Mn elements associated with the Fuel Burning source agree with Banerjee et al. (2015).

Table 9. Emission sources obtained for $\mathrm{PM}_{2.5}$ from the $\mathrm{BC}$ site

\begin{tabular}{|c|c|c|c|c|c|c|}
\hline Element & Soil dust & Metallurgy & Fuel burning & Community & $\begin{array}{c}\% \\
\text { Variance }\end{array}$ & $\begin{array}{c}\% \\
\text { Cumulative }\end{array}$ \\
\hline $\mathbf{C a}$ & 0.966 & & & 0.939 & 38.350 & 38.350 \\
\hline $\mathbf{F e}$ & 0.932 & & & 0.888 & & \\
\hline $\mathbf{T i}$ & 0.905 & & & 0.906 & & \\
\hline $\mathbf{Z n}$ & 0.697 & & & 0.830 & & \\
\hline $\mathbf{C r}$ & 0.668 & & & 0.934 & & \\
\hline $\mathbf{K}$ & & 0.933 & & 0.823 & 22.795 & 61.145 \\
\hline $\mathbf{C l}$ & & 0.884 & & 0.798 & & \\
\hline $\mathbf{M G F}$ & & 0.592 & & 0.684 & & \\
\hline $\mathbf{S}$ & & & 0.916 & 0.911 & 21.897 & 83.042 \\
\hline $\mathbf{M n}$ & & & 0.719 & 0.592 & & \\
\hline
\end{tabular}

At the NO site, the possible emission sources were obtained, Table 10 shows that the rotated matrix of the data (VARIMAX) results in three significant components, which were associated with Industry, Coal Burning and Soil Dust. In the principal component analysis these three explain $100 \%$ of the variability of the data.

The $\mathrm{Ni}, \mathrm{V}, \mathrm{Zn}, \mathrm{Cr}$ and $\mathrm{Mn}$ elements corresponding to the Industry source agree with those reported by Banerjee et al. (2015). The coal burning source (Cl, FGM, S, Fe) agrees with that reported by Owoade et al. (2015). K and Ca were assigned to the Soil Dust source and agrees with that reported by Alvarez and Suarez (2020).

Table 10. Emission sources obtained for $\mathrm{PM}_{2.5}$ from the NO

\begin{tabular}{|c|c|c|c|c|c|c|}
\hline Element & Industry & $\begin{array}{c}\text { Coal } \\
\text { burning }\end{array}$ & Soil dust & Community & $\begin{array}{c}\% \\
\text { Variance }\end{array}$ & $\begin{array}{c}\% \\
\text { Cumulative }\end{array}$ \\
\hline $\mathbf{N i}$ & 0.984 & & & 1.000 & 43.460 & 43.460 \\
\hline $\mathbf{V}$ & 0.971 & & & 1.000 & & \\
\hline $\mathbf{Z n}$ & 0.899 & & & 1.000 & & \\
\hline $\mathbf{C r}$ & 0.853 & & & 1.000 & & \\
\hline $\mathbf{M n}$ & 0.823 & & & 1.000 & & \\
\hline $\mathbf{C l}$ & & 0.999 & & 1.000 & 32.069 & \\
\hline $\mathbf{M G F}$ & & -0.985 & & 1.000 & & \\
\hline $\mathbf{S}$ & & -0.763 & & 1.000 & & \\
\hline $\mathbf{F e}$ & & 0.700 & & 1.000 & & \\
\hline $\mathbf{K}$ & & & 0.989 & 1.000 & 24.471 & \\
\hline $\mathbf{C a}$ & & & 0.846 & 1.000 & & \\
\hline
\end{tabular}

In SL, Table 11 shows the possible emission sources and it is observed that the rotated matrix of the data (VARIMAX) results in three significant components, which were associated with Industry, Soil Dust and Vehicular. The principal component analysis shows that these three components explain $100 \%$ of the variability of the data.

350 The source associated with Soil Dust with the elements $\mathrm{Fe}, \mathrm{V}, \mathrm{Ca}, \mathrm{S}, \mathrm{Cr}$ and Ti, coincides with that related by Almeida et al. (2020) and Owoade et al. (2015). The elements Cl, Mn, K and Zn being associated with 
the Metallurgy source, agrees with Owoade et al. (2015). Cu and MGF were associated with the

Table 11. Emission sources obtained for $\mathrm{PM}_{2.5}$ from the SL site.

\begin{tabular}{|c|c|c|c|c|c|c|}
\hline Element & Soil dust & Metallurgy & Vehicular & Community & $\begin{array}{c}\% \\
\text { Variance }\end{array}$ & $\begin{array}{c}\% \\
\text { Cumulative }\end{array}$ \\
\hline $\mathbf{F e}$ & 0.952 & & & 1.000 & 41.600 & 41.600 \\
\hline $\mathbf{V}$ & 0.888 & & & 1.000 & & \\
\hline $\mathbf{C a}$ & 0.852 & & & 1.000 & & \\
\hline $\mathbf{S}$ & 0.850 & & & 1.000 & & \\
\hline $\mathbf{C r}$ & 0.839 & & 1.000 & & \\
\hline $\mathbf{T i}$ & 0.819 & & & 1.000 & & \\
\hline $\mathbf{C l}$ & & 0.994 & & 1.000 & 37.765 & 79.365 \\
\hline $\mathbf{M n}$ & & 0.993 & & 1.000 & & \\
\hline $\mathbf{K}$ & & 0.977 & & 1.000 & & \\
\hline $\mathbf{Z n}$ & & 0.792 & & 1.000 & & \\
\hline $\mathbf{C u}$ & & & 0.889 & 1.000 & 20.635 & 100.000 \\
\hline $\mathbf{M G F}$ & & & 0.876 & 1.000 & & \\
\hline
\end{tabular}

356

357

358

359

360

361

362

363

364

365

366

367

368

369

370

371

372

373

In ZN, Table 12, results in three significant components, which were associated with Soil Dust, Vehicular and FGM. The principal component analysis shows that these three components explain $100 \%$ of the variability of the data.

The Soil Dust source was associated with the elements $\mathrm{Fe}, \mathrm{Zn}, \mathrm{Ti}, \mathrm{Cl}$ and $\mathrm{Ca}$, which are in agreement with Almeida et al. (2020) and SDA (2009). THE source assigned as Vehicular (Cr, Mn, K, S) agrees with Owoade et al. (2015). FGM indicates another source.

Table 12. Emission sources obtained for $\mathrm{PM}_{2.5}$ from the $\mathrm{ZN}$ site

\begin{tabular}{|c|c|c|c|c|c|c|}
\hline Element & Soil dust & Vehicular & MGF & Community & $\begin{array}{c}\% \\
\text { Variance }\end{array}$ & $\begin{array}{c}\% \\
\text { Cumulative }\end{array}$ \\
\hline $\mathbf{F e}$ & 0.997 & & & 1.000 & 50.408 & 50.408 \\
\hline $\mathbf{Z n}$ & 0.993 & & & 1.000 & & \\
\hline $\mathbf{T i}$ & 0.941 & & & 1.000 & & \\
\hline $\mathbf{C l}$ & -0.930 & & & 1.000 & & \\
\hline $\mathbf{C a}$ & 0.850 & & & 1.000 & & \\
\hline $\mathbf{C r}$ & & 0.671 & & 1.000 & 34.834 & 85.242 \\
\hline $\mathbf{M n}$ & & 0.973 & & 1.000 & & \\
\hline $\mathbf{K}$ & & 0.961 & & 1.000 & & \\
\hline $\mathbf{S}$ & & 0.950 & & 1.000 & & \\
\hline $\mathbf{M G F}$ & & & 0.975 & 1.000 & 14.758 & 100.000 \\
\hline
\end{tabular}

Table 13 shows the possible emission sources obtained at the SC site, where it is observed that the rotated matrix of the data (VARIMAX) results in three significant components, which were associated with Soil Dust, Hydrocarbons and Industry. The principal component analysis shows that these three components explain $92.8 \%$ of the variability of the data.

The source corresponding to Soil Dust which presents the elements $\mathrm{Zn}, \mathrm{K}, \mathrm{Cl}, \mathrm{Ti}, \mathrm{Mn}, \mathrm{Fe}, \mathrm{MGF}$ and $\mathrm{Ca}$ is in agreement with Owoade et al. (2015). Cu, S and V were assigned for the factor Hydrocarbons which agrees with Almeida et al. (2020) and Núñez (2019). The Cr element was assigned the Industry source which is in agreement with the data presented by Almeida et al. (2020). 
Table 13. Emission sources obtained for $\mathrm{PM}_{2.5}$ from the SC site.

\begin{tabular}{|c|c|c|c|c|c|c|}
\hline Element & Soil dust & Hydrocarbons & Industry & Community & $\begin{array}{c}\% \\
\text { Variance }\end{array}$ & $\begin{array}{c}\% \\
\text { Cumulative }\end{array}$ \\
\hline $\mathbf{Z n}$ & 0.996 & & & 0.893 & 47.796 & 47.796 \\
\hline $\mathbf{K}$ & 0.970 & & & 0.936 & & \\
\hline $\mathbf{C l}$ & 0.943 & & & 0.950 & & \\
\hline $\mathbf{T i}$ & 0.790 & & 0.962 & & \\
\hline $\mathbf{M n}$ & 0.790 & & & 0.826 & & \\
\hline $\mathbf{F e}$ & 0.786 & & 0.886 & & \\
\hline $\mathbf{M G F}$ & 0.709 & & 0.944 & & \\
\hline $\mathbf{C a}$ & 0.609 & & & 0.941 & & \\
\hline $\mathbf{C u}$ & & 0.898 & & 0.968 & 27.923 & 75.718 \\
\hline $\mathbf{S}$ & & 0.896 & & 0.996 & & \\
\hline $\mathbf{V}$ & & 0.889 & & 0.838 & & \\
\hline $\mathbf{C r}$ & & & -0.961 & 0.997 & 17.087 & 92.805 \\
\hline
\end{tabular}

380

381

382

383

384

385

386

387

388

389

390

391

392

393

394

395

396

397

398

399

400

401

402

According to the emissions inventory conducted by ProAire (2018), the ZMVT ranks fourth among the most polluted in the country. Mobile sources, represented by motor vehicles, are responsible for the greatest load of air pollutants in the entity. In the State of Mexico, $16 \%$ of the industry is located in the Toluca Valley. Extractive activities, the operation of furnaces for the manufacture of red brick, as well as soil erosion and forest fires also contribute to this problem, which explains the variability in the determination of the sources. Table 14 shows a summary of the emission sources.

Table 14. Summary of possible sources of $\mathrm{PM}_{2.5}$ emissions at the study sites.

\begin{tabular}{|l|l|l|l|}
\hline Site & \multicolumn{3}{|c|}{ Possible Emission Sources } \\
\hline SM & Soil dust & Sulfates & Hydrocarbons \\
\hline SC & Soil dust & Industry & Hydrocarbons \\
\hline NO & Soil dust & Industry & Coal burning \\
\hline CB & Soil dust & Metallurgy & Fuel burning \\
\hline SL & Soil dust & Metallurgy & Vehicular \\
\hline ZN & Soil dust & MGF & Vehicular \\
\hline
\end{tabular}

The results obtained in this study for the possible sources of $\mathrm{PM}_{2.5}$ emissions are in accordance with research conducted in other cities around the world by different researchers, as shown in Table 15. 
Table 15. Possible emission sources obtained in this work and their comparison with other results at the international level

\begin{tabular}{|c|c|c|c|}
\hline Reference & Site & Emission Source & Pollutant \\
\hline \multirow{9}{*}{$\begin{array}{l}\text { This } \\
\text { research }\end{array}$} & \multirow{9}{*}{$\begin{array}{l}\text { Toluca Valley } \\
\text { Metropolitan } \\
\text { Area, Mexico }\end{array}$} & Soil dust & $\begin{array}{l}\text { Ca, Ti, Cu, Mn, Cr, K, Ni, Cl, Fe, Zn, V, S, } \\
\text { MGF }\end{array}$ \\
\hline & & Sulfates & $\mathrm{Pb}, \mathrm{S}$ \\
\hline & & Hydrocarbons & MGF, V, Zn, Cu, S \\
\hline & & Metallurgy & $\mathrm{K}, \mathrm{Cl}, \mathrm{MGF}, \mathrm{Mn}, \mathrm{Zn}, \mathrm{Cr}, \mathrm{S}$ \\
\hline & & Industry & $\mathrm{Ni}, \mathrm{V}, \mathrm{Zn}, \mathrm{Cr}, \mathrm{Mn}$ \\
\hline & & Coal burning & $\mathrm{Cl}, \mathrm{MGF}, \mathrm{S}, \mathrm{Fe}$ \\
\hline & & Fuel burning & $\mathrm{S}, \mathrm{Mn}$ \\
\hline & & Vehicular & $\mathrm{Cu}, \mathrm{MGF}, \mathrm{Fe}, \mathrm{Zn}, \mathrm{Ti}, \mathrm{Cl}, \mathrm{Ca}$ \\
\hline & & MGF & MGF \\
\hline \multirow{8}{*}{$\begin{array}{l}\text { (Almeida } \\
\text { et al. 2020) }\end{array}$} & \multirow{8}{*}{$\begin{array}{l}\text { Urban areas in } \\
\text { Europe and } \\
\text { Central Asia }\end{array}$} & Secondary sulfate & Sulfate, $\mathrm{Br}, \mathrm{Pb}, \mathrm{C}$ \\
\hline & & Biomass burning & $\mathrm{K}, \mathrm{Pb}, \mathrm{Cu}, \mathrm{BC}, \mathrm{Cl}, \mathrm{Zn}, \mathrm{Br}, \mathrm{S}$ \\
\hline & & Gasoline combustion & $\mathrm{V}, \mathrm{Ni}, \mathrm{S}, \mathrm{SO}_{3}$ \\
\hline & & Coal combustion & $\mathrm{SO}_{2}$ \\
\hline & & Industrial emissions & $\mathrm{Mn}, \mathrm{Fe}, \mathrm{Pb}, \mathrm{Zn}, \mathrm{Cu}$ y $\mathrm{Cr}, \mathrm{Ca}, \mathrm{Al}$ \\
\hline & & Traffic & $\begin{array}{l}\mathrm{OC}^{\mathrm{a}}, \mathrm{EC}^{\mathrm{b}} \text { y } \mathrm{BC}^{\mathrm{c}} . \mathrm{Ba}, \mathrm{Cu}, \mathrm{Mn}, \mathrm{Pb}, \mathrm{Zn}, \mathrm{Al}, \\
\mathrm{Ca}, \mathrm{Fe}, \mathrm{Mn}, \mathrm{Si} \mathrm{y} \mathrm{Ti}\end{array}$ \\
\hline & & Land (soil/crust) & $\mathrm{Al}, \mathrm{Ca}, \mathrm{Fe}, \mathrm{Mn}, \mathrm{Si}$ y Ti, Cr, V y Ni \\
\hline & & Salt & Sea salt \\
\hline \multirow{4}{*}{$\begin{array}{l}\text { (Álvarez y } \\
\text { Suárez } \\
\text { 2020) }\end{array}$} & \multirow{4}{*}{$\begin{array}{l}\text { Urban sites in } \\
\text { the Mantaro } \\
\text { Valley, Peru }\end{array}$} & Soil dust & $\mathrm{Al}, \mathrm{Ca}, \mathrm{Fe}, \mathrm{Si}, \mathrm{Ti}, \mathrm{K}$ \\
\hline & & Smelting & As, Zn, Pb, S, K, Ti, Si \\
\hline & & Biomass burning & $\mathrm{K}$ \\
\hline & & Vehicles & As \\
\hline \multirow{6}{*}{$\begin{array}{l}\text { (Núñez } \\
\text { 2019) }\end{array}$} & \multirow{6}{*}{$\begin{array}{l}\text { Barranquilla, } \\
\text { Colombia }\end{array}$} & Fuel oil burning & $\mathrm{Ni}, \mathrm{V}$ y $\mathrm{Cu}$ \\
\hline & & Fertilizer production & $\mathrm{Ca}, \mathrm{P}, \mathrm{K}^{+}$y SO4 $4^{2-}$ \\
\hline & & Marine Aerosol & $\mathrm{Mg}, \mathrm{Cl}, \mathrm{Na}^{+}, \mathrm{K}^{+}, \mathrm{Mg}^{2+}$ y Cl \\
\hline & & $\begin{array}{l}\text { Secondary sources } \\
\text { and civil works }\end{array}$ & $\begin{array}{l}\mathrm{Ca}^{2+}, \mathrm{NO}^{3-} \\
\text { y SO} 4^{2-}\end{array}$ \\
\hline & & Resuspended soil & $\mathrm{BC}, \mathrm{Mn}, \mathrm{Zn}, \mathrm{Cu}$ y $\mathrm{Pb}$ \\
\hline & & Suelo resuspendido & $\mathrm{Al}, \mathrm{Si}, \mathrm{K}, \mathrm{Ti}, \mathrm{Mn}$ y Ca \\
\hline \multirow{4}{*}{$\begin{array}{l}\text { (Owoade } \\
\text { et al. 2015) }\end{array}$} & \multirow{4}{*}{$\begin{array}{l}\text { Road } \\
\text { Ife-lbadan, } \\
\text { Nigeria }\end{array}$} & Coking coal & $\mathrm{Na}, \mathrm{S}, \mathrm{Cl}, \mathrm{K}, \mathrm{Fe}, \mathrm{Zn}, \mathrm{As}, \mathrm{Br}, \mathrm{Pb}, \mathrm{BC}$ \\
\hline & & Soil & $\mathrm{Na}, \mathrm{Mg}, \mathrm{Al}, \mathrm{Si}, \mathrm{S}, \mathrm{k}, \mathrm{Ca}, \mathrm{Ti}, \mathrm{Mn}, \mathrm{Fe}, \mathrm{Zn}$ \\
\hline & & Electronic waste & $\mathrm{Na}, \mathrm{Mg}, \mathrm{Si}, \mathrm{K}, \mathrm{Cu}, \mathrm{Zn}, \mathrm{Ga}, \mathrm{Cd}, \mathrm{Sn}$ \\
\hline & & Metallurgy & $\begin{array}{l}\mathrm{Mg}, \mathrm{Al}, \mathrm{S}, \mathrm{Cl}, \mathrm{K}, \mathrm{Ca}, \mathrm{Mn}, \mathrm{Fe}, \mathrm{Zn}, \mathrm{As}, \mathrm{Cd}, \mathrm{Pb}, \\
\mathrm{BC}\end{array}$ \\
\hline \multirow{6}{*}{$\begin{array}{l}\text { (Banerjee } \\
\text { et al., 2015) }\end{array}$} & \multirow{6}{*}{ India } & $\begin{array}{l}\text { Crustal resuspensions } \\
\text { and road dust }\end{array}$ & $\mathrm{Al}, \mathrm{Ca}, \mathrm{Fe}, \mathrm{Na}$ y $\mathrm{Mg}$ \\
\hline & & Vehicle emissions & $\mathrm{Fe}, \mathrm{Cu}, \mathrm{Pb}, \mathrm{Cr}, \mathrm{Ni}, \mathrm{Mn}, \mathrm{Ba}$ y $\mathrm{Zn}$ \\
\hline & & Industrial emissions & Co, Cr, Zn, V, Ni, Mn, Cd \\
\hline & & Gasoline combustion & $\mathrm{K}, \mathrm{NH}_{4}^{+}, \mathrm{SO}_{4}^{-}, \mathrm{As}, \mathrm{Te}, \mathrm{S}, \mathrm{Mn}$ \\
\hline & & Marine aerosols & $\mathrm{Na}, \mathrm{Mg}, \mathrm{K}$ \\
\hline & & $\begin{array}{l}\text { Biomass / waste } \\
\text { burning }\end{array}$ & $\mathrm{Cd}, \mathrm{V}, \mathrm{K}, \mathrm{Cr}, \mathrm{As}, \mathrm{TC}, \mathrm{Na}, \mathrm{K}, \mathrm{NH}^{+}, \mathrm{NO}^{-}, \mathrm{OC}^{\mathrm{a}}$ \\
\hline \multirow{5}{*}{ (SDA 2009) } & \multirow{5}{*}{$\begin{array}{c}\text { Bogotá, } \\
\text { Colombia } \\
\text { High } \\
\text { vehicular } \\
\text { traffic area }\end{array}$} & $\begin{array}{l}\text { Resuspended dust / } \\
\text { Natural soil }\end{array}$ & $\mathrm{Mg}, \mathrm{Na}, \mathrm{B}, \mathrm{Ca}$ y $\mathrm{Al}$ \\
\hline & & Vehicles + Fe & $\mathrm{SO}^{2}=\mathrm{NO}^{-}, \mathrm{NH}^{+}, \mathrm{Cl}-, \mathrm{Fe}, \mathrm{Pb}$ \\
\hline & & Industry & $\mathrm{Cr}, \mathrm{Ni}, \mathrm{Pb}$ \\
\hline & & Diesel vehicles & $\mathrm{Cu}, \mathrm{Cl}^{-}$ \\
\hline & & $\mathrm{PO}^{-3}, \mathrm{Fe}$ & $\mathrm{PO}^{-3}+\mathrm{Fe}$ \\
\hline \multirow{2}{*}{$\begin{array}{c}\text { (Rojas et al. } \\
1990)\end{array}$} & \multirow{2}{*}{$\begin{array}{l}\text { Santiago de } \\
\text { Chile }\end{array}$} & Soil dust / Industrial & $\mathrm{Al}, \mathrm{Si}, \mathrm{P}, \mathrm{Mn}, \mathrm{Fe}, \mathrm{Cu}, \mathrm{Zn}, \mathrm{Pb}$ \\
\hline & & Sulfate & $\mathrm{P}, \mathrm{S}, \mathrm{Zn}, \mathrm{Pb}$, Mass \\
\hline
\end{tabular}


a Organic carbon, ${ }^{\text {b }}$ Elemental Carbon, ${ }^{\mathrm{c}}$ Black carbon.

\section{Identification of risk sources}

413 In order to determine the sources of risk to the health of the three sensitive classes of the population, due 414 to PM2.5 inhalation, the emission sources obtained were considered and their elemental risk was assigned 415 to each element.

Figure 3 shows the sources of risk to the health of the population in SM, which are Soil Dust, Hydrocarbons and Sulfates, where Soil Dust is the highest risk source and Hydrocarbons the lowest. The population that obtained the highest risk by inhalation of soil dust is children from 6 to 12 years old, so they are the most prone to suffer some of the diseases caused by the elements that make up the source.

\section{Health risk from $\mathrm{PM}_{2.5}$ inhalation caused by SM emission} sources

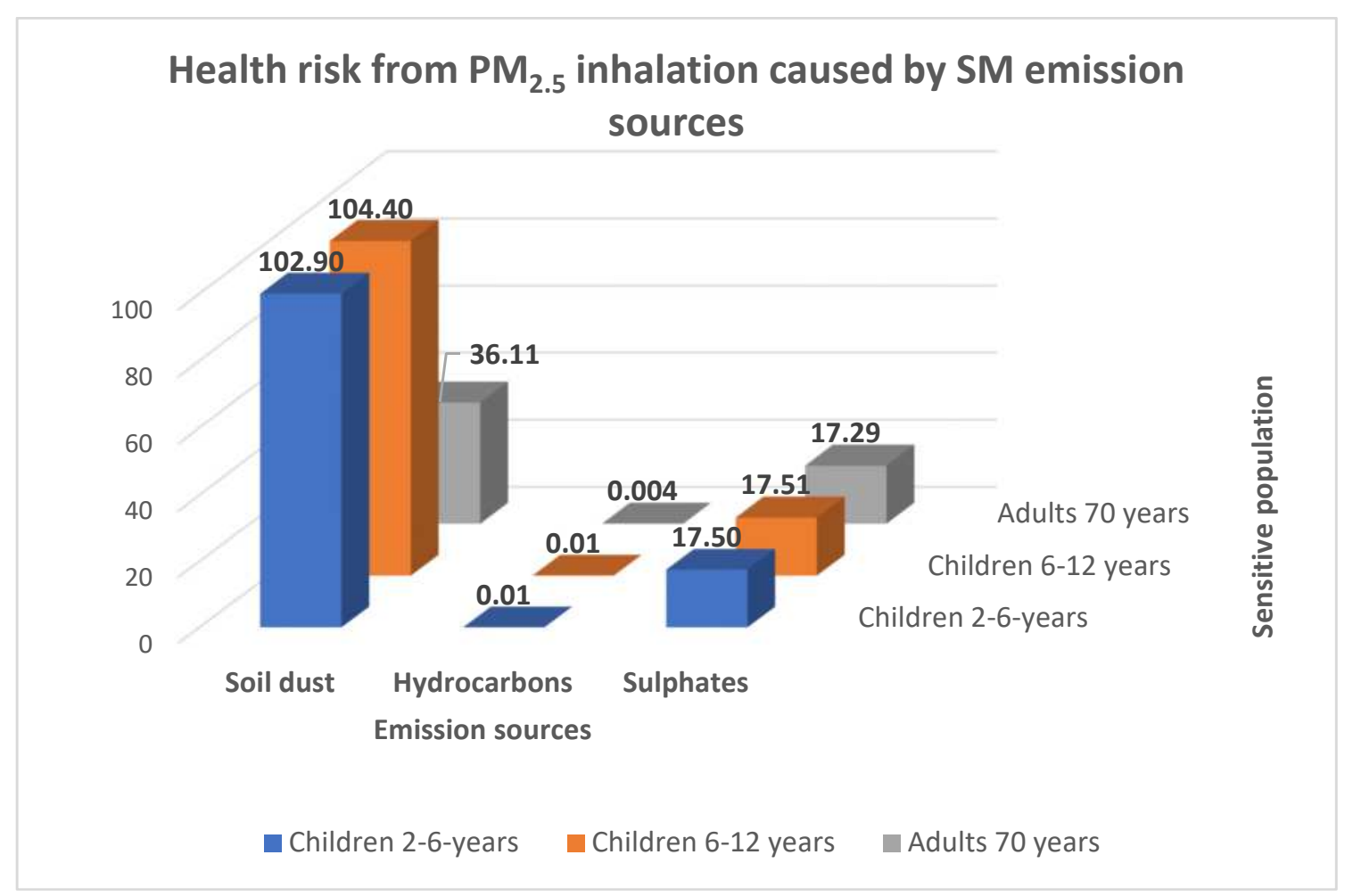

Figure 3. Health risk due to $\mathrm{PM}_{2.5}$ inhalation caused by SM emission sources.

The CB site has three sources of risk, which are soil dust, metallurgy and fuel burning, as shown in Figure 4. The population that is most sensitive to the components of the Metallurgy source are children from 6 to 


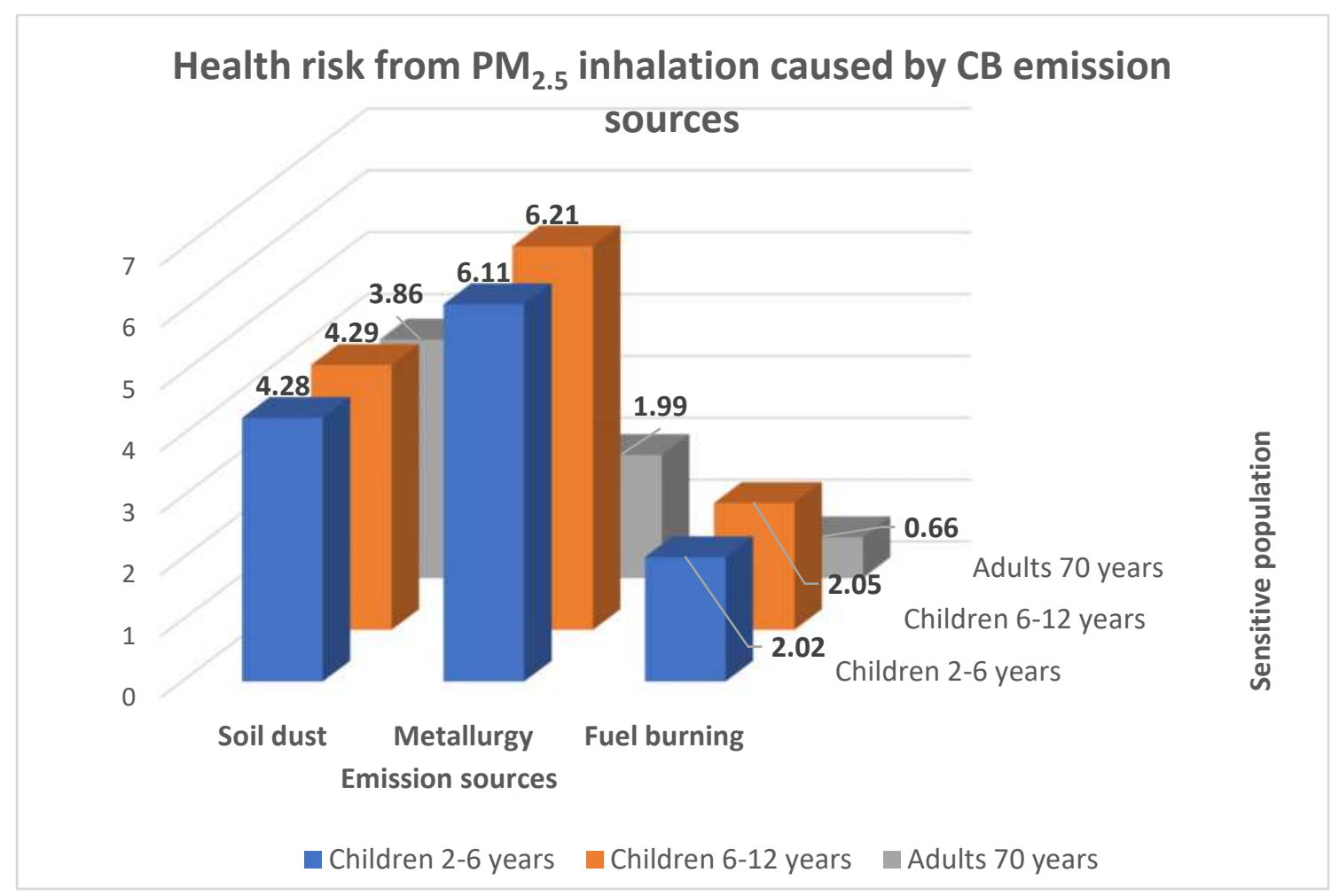

Figure 4. Health risk due to $\mathrm{PM}_{2.5}$ inhalation caused by $\mathrm{CB}$ emission sources

At the NO site, the sources of risk were determined for Industry and Coal Burning, which are presented in Figure 5. At this site, only the two sources mentioned are considered because the Reference Doses for the elements $\mathrm{K}$ and $\mathrm{Ca}$ were not available, which determined the third source considered as Soil Dust according to Alvarez and Suarez (2020) and Owoade et al. (2015). The source with the highest risk is Coal burning and the population with the highest sensitivity is children from 6 to 12 years old, for the same 443 source. 


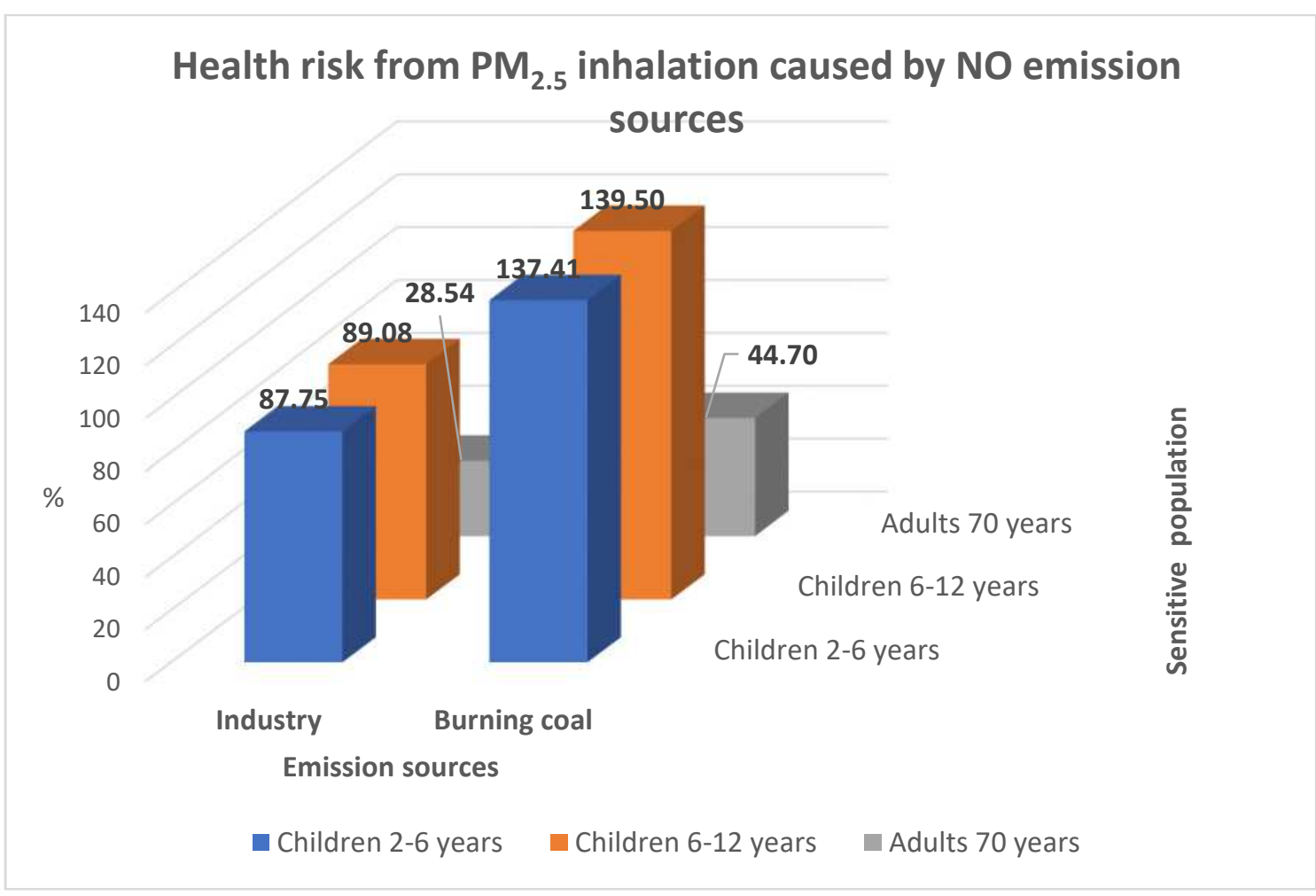

Figure 5. Health risk due to $\mathrm{PM}_{2.5}$ inhalation caused by $\mathrm{NO}$ emission sources.

Figure 6 shows the sources of health risks for the SL area, which are Metallurgy, Soil Dust and Vehicular. Metallurgy is the highest risk source and Fuel Burning is the lowest. The population that obtained the highest risk due to inhalation of the elements that form the Metallurgy source are children from 6 to 12 years old, therefore they are the most prone to suffer some of the diseases caused by the elements that make up the source 


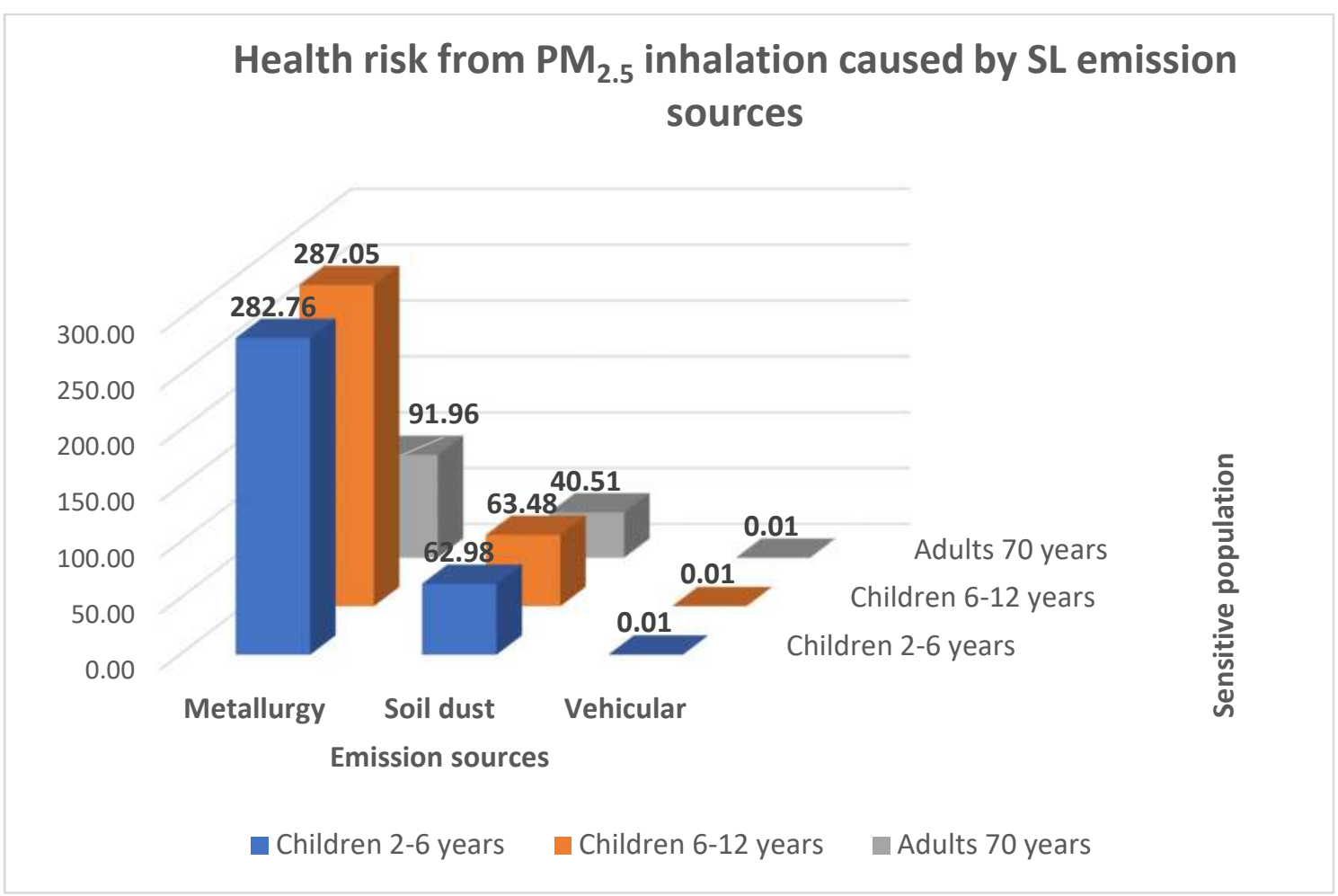

Figure 6. Health risk due to $\mathrm{PM}_{2.5}$ inhalation caused by SL emission sources

Figure 7 shows the sources of health risk for the sensitive ZN classes, which are Vehicular, FGM and Metallurgy. The Metallurgy source is the highest risk and FGM the lowest. The population that obtained the highest risk by inhalation of the elements that compose the Metallurgy source are children from 6 to 12 years old, so they are the most prone to suffer some of the diseases caused by these elements. 


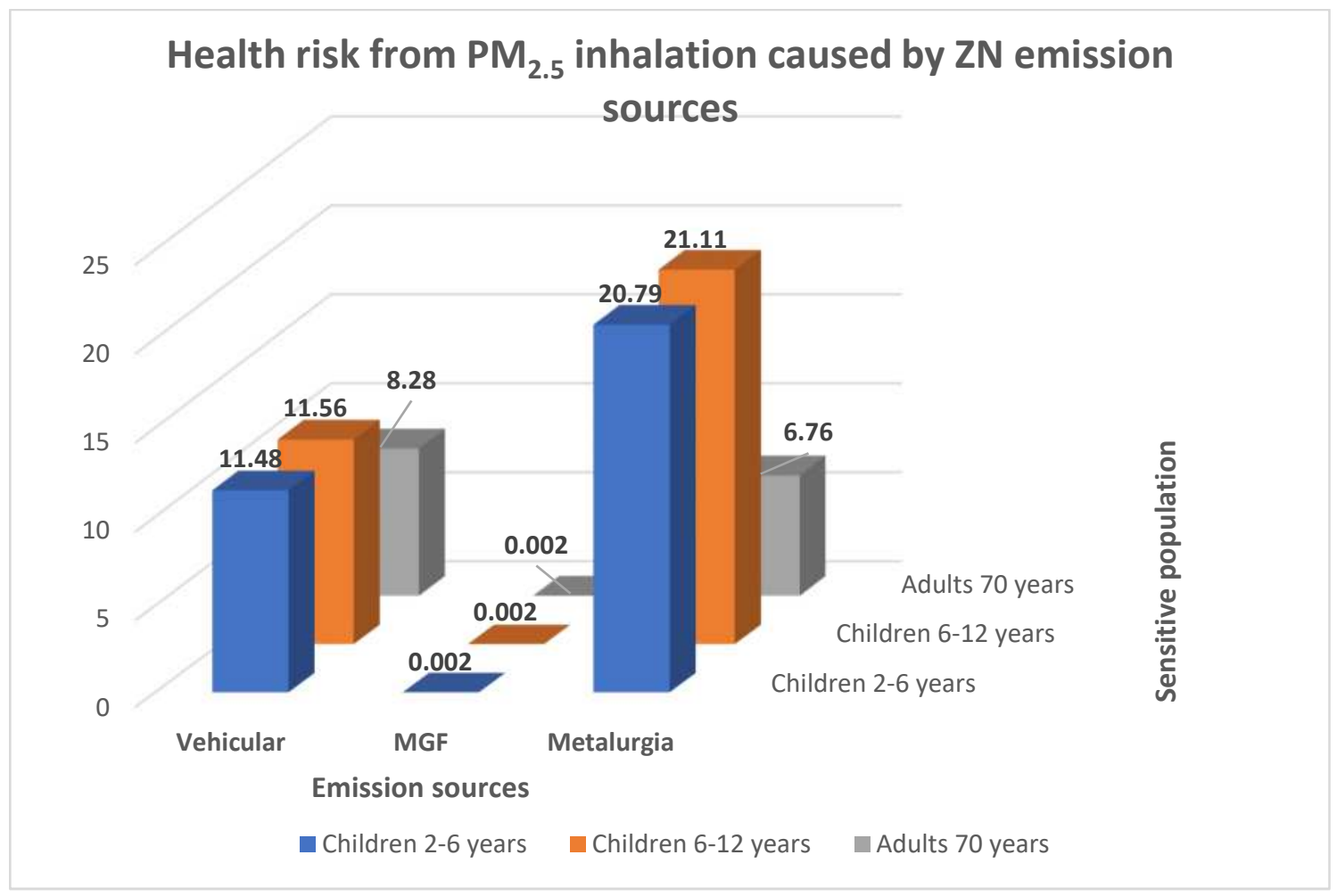

Figure 7. Health risk due to $\mathrm{PM}_{2.5}$ inhalation caused by $\mathrm{ZN}$ emission sources

Figure 8 presents the results of the health risk sources for inhalation of Soil Dust, Industry and Hydrocarbons in the SC area. The highest inhalation risk is for the Soil Dust Source and the lowest for Hydrocarbons. Children from 6 to 12 years old are the sensitive population with the highest risk of contracting diseases due to the inhalation of the elements that compose the Soil Dust source.

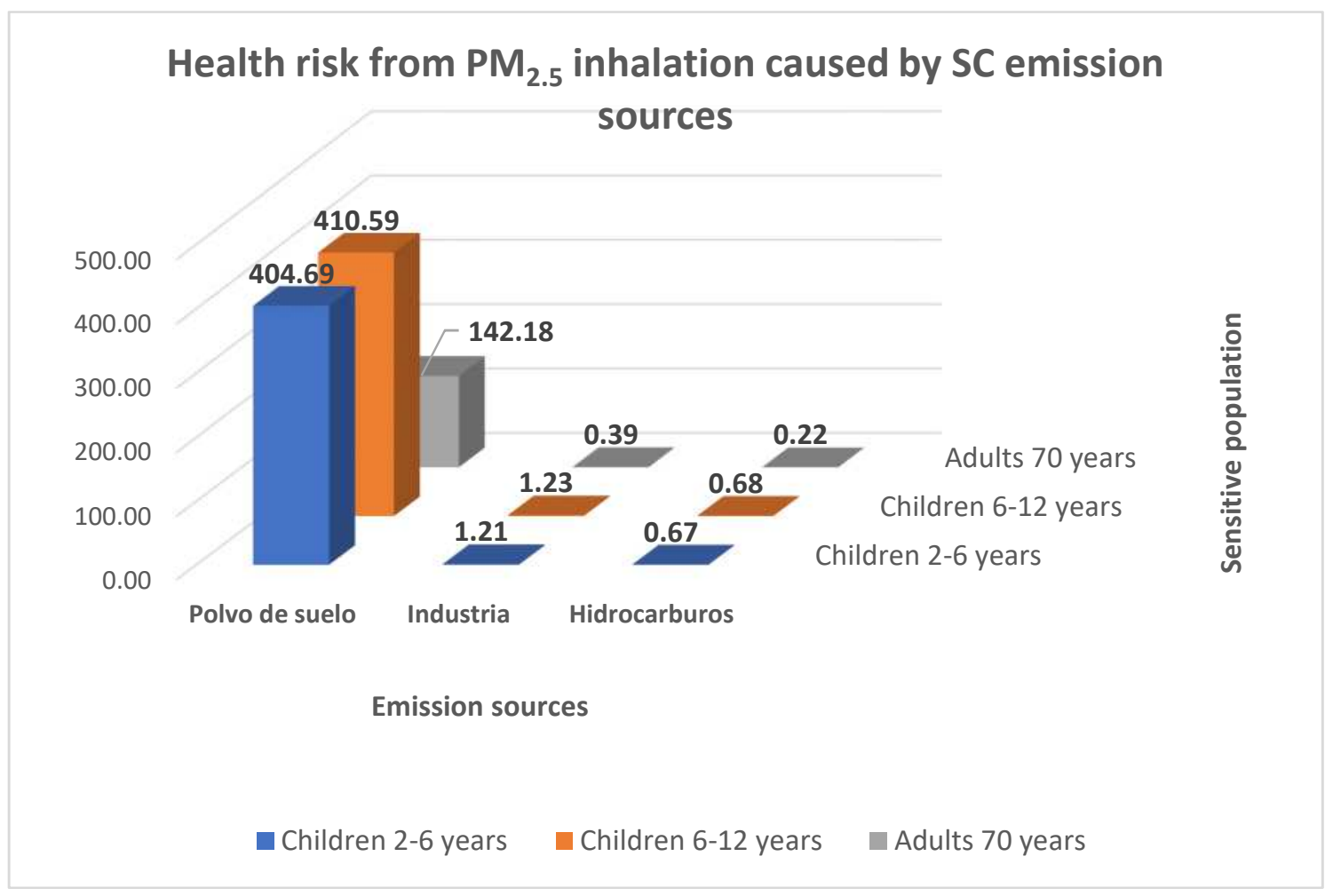


472

Table 16 presents the CQE of the sources of risk obtained and the possible diseases that can be contracted by sensitive groups of the population.

Table 16. Pathologies associated with the elemental chemical composition of PM2.5 (Lenntech 2021; ATSRD 2018; USEPA 2016 and Montero 2010)

\begin{tabular}{|c|c|}
\hline Elements & Diseases \\
\hline $\mathrm{S}, \mathrm{Ni}$ & Asthma, Respiratory arrest \\
\hline S & $\begin{array}{l}\text { Alterations of hormonal metabolism, } \\
\text { Bronchopneumonia, Fever, Damage to liver } \\
\text { functions }\end{array}$ \\
\hline $\mathrm{S}, \mathrm{Cl}, \mathrm{Ni}$ & Cardiac damage \\
\hline $\mathrm{S}, \mathrm{Pb}$ & Damage to kidney functions \\
\hline $\mathrm{S}, \mathrm{Cl}, \mathrm{Mn}, \mathrm{Cu}$ & Headache \\
\hline $\mathrm{S}, \mathrm{Cl}$ & Chest pain and obstruction \\
\hline $\begin{array}{l}\mathrm{S}, \mathrm{V}, \mathrm{Mn}, \mathrm{Cl} \\
\mathrm{Ni}\end{array}$ & Bronchitis \\
\hline $\mathrm{S}, \mathrm{V}, \mathrm{Cr}$ & Nose irritation \\
\hline $\mathrm{S}, \mathrm{Cl}, \mathrm{V}$ & Throat irritation \\
\hline $\mathrm{S}, \mathrm{Cl}, \mathrm{Cr}, \mathrm{Pb}$ & Death \\
\hline $\mathrm{Cl}$ & Itching or burning sensation in nose and throat \\
\hline $\mathrm{Zn}, \mathrm{Ti}$ & Interstitial fibrosis \\
\hline $\mathrm{Zn}$ & $\begin{array}{l}\text { Metal fume fever, Anemia and pancreatic } \\
\text { damage }\end{array}$ \\
\hline
\end{tabular}




\section{Conclusions}

491

492

493

494

495

496

497

498

499

500

501

502

503

504

505

506

507

508

509

510

511

512

513

514
1. The gravimetric concentration of $\mathrm{PM}_{2.5}$, was exceeded during the entire one-year study period, in accordance with the NOM-025-SSA1-2014 Standard.

2. CQE was determined for $\mathrm{P}, \mathrm{S}, \mathrm{K}, \mathrm{Ca}, \mathrm{Ti}, \mathrm{V}, \mathrm{Cr}, \mathrm{Mn}, \mathrm{Fe}, \mathrm{Co}, \mathrm{Ni}, \mathrm{Y}, \mathrm{Cu}$ and $\mathrm{Pb}$, through the PIXE atomic technique.

3. Nine possible emission sources were identified for CQE, namely soil dust, sulfates, industry, metallurgy, hydrocarbons, coal burning, fuel burning, vehicles and FGM.

4. The inhalation risks of $\mathrm{CQE}$ present in $\mathrm{PM}_{2.5}$ particles for the six sampling sites were high, which implies that there is a high probability of developing some of the diseases that can be caused by these elements.

5. The population with the highest health risk from inhalation of the elemental chemical composition present in $\mathrm{PM}_{2.5}$ was children aged 6 to 12 years at all sites. It is worth noting that both child populations are vulnerable to the risk of inhalation of $\mathrm{PM}_{2.5}$.

6. With the risks obtained and the possible emission sources, the sources of risk can be determined. This indicates which source may be the most harmful to the health of the population.

7. In ZMVT the elements $\mathrm{Cl}, \mathrm{S}, \mathrm{Cr}, \mathrm{Ti}, \mathrm{Mn}$ and $\mathrm{Pb}$ require monitoring, based on the risk analysis, because they have an impact on the health of the population.

8. The risk obtained for this work is considered only for CQE; the risk for other environmental pollutants such as bacteria, fungi, polycyclic aromatic hydrocarbons, among others, which are present in $\mathrm{PM}_{2.5}$, is not considered.

9. Based on the knowledge of the pollutants that present a risk to the health of the population that inhales them, it is now necessary to establish mitigation or remediation strategies. 


\section{Declarations}

Ethics approval and consent to participate

Not applicable

Consent for publication

\section{Not applicable}

Availability of data and materials

All data generated or analyzed during this study are available from the corresponding author on reasonable request.

Competing interests

The authors declare that they have no competing interests.

Funding

To National Institute for Nuclear Research for the support to this research

Author's contributions

All authors have contributed equally to the manuscript.

Author's contributions

Raúl Venancio Díaz Godoy: This author contributed equally to the research work of this manuscript as well as to its writing

Jaime Moreno Alcántara: This author contributed equally to the research work of this manuscript as well as to its writing

Judith Castellanos Moguel: This author contributed equally to the research work of this manuscript as well as to its writing

María Teresa Núñez Cardona: This author contributed equally to the research work of this manuscript as well as to its writing

Martha Patricia Sierra Vargas: This author contributed equally to the research work of this manuscript as well as to its writing

Octavio Gamaliel Aztatzi Aguilar: This author contributed equally to the research work of this manuscript as well as to its writing

Angélica Flores Ortiz: This author contributed equally to the research work of this manuscript as well as to its writing

\section{Acknowledgements}

The authors would like to express their gratitude to the following organizations and individuals: To SEP-CONACYT "Sectorial Research Fund for to Education". CB-2015-01-256751; To National Institute for Nuclear Research for the support to this research; to metrology department of ININ for the realization of gravimetric for the samples obtained; to the Automatic Network for Atmospheric Monitoring of the Valley of Toluca (staff: Rodrigo Castaneda, Luis Rico), for the support to the sampling. 


\section{References}

Almeida SM, Manousakas M, Diapoul E, Kertesz Z, Samek L, Hristova E, Šega K, Padilla Alvarez R, Belis CA, Eleftheriadis K (2020) Ambient particulate matter source apportionment using receptor modelling in European and Central Asia urban areas. Environmental Pollution, Volume 266, Part 3,2020,115199. https://doi.org/10.1016/j.envpol.2020.115199

Álvarez-Tolentino D, Suárez-Salas L (2020) Aporte cuantitativo de las fuentes de $\mathrm{PM}_{10}$ y $\mathrm{PM}_{2.5}$ en sitios urbanos del Valle del Mantaro, Perú. Revista Internacional de Contaminación Ambiental, [S.I.], v. 36, n. 4, p. 875-892. http://dx.doi.org/10.20937/RICA.53473.

ATSDR (2018) Niveles mínimos de riesgo (LMR) para sustancias peligrosas. Agencia para Sustancias Tóxicas y el Registro de Enfermedades. https://www.atsdr.cdc.gov/mrls/index.html. Consultado el 19 de febrero de 2021.

Banerjee T, Murari V, Kumar M, Raju MP (2015) Source apportionment of airborne particulates through receptor modeling: Indian scenario. Atmospheric Research, Volumes 164-165, Pages 167-187. https://doi.org/10.1016/j.atmosres.2015.04.017

CEPIS y OPS (1997) Curso de Autoinstrucción en metodología de identificación y evaluación de riesgos para la salud en sitios contaminados. http://cidta.usal.es/riesgos/CD1/sitios contaminados/www.cepis.opsoms.org/tutorial3/e/c asos/caso1/evalries.html. Consultado el 18 de enero del 2021.

COESPO (2019) Zonas metropolitanas del Estado de México. http://coespo.edomex.gob.mx/zonas metropolitanas. Consultado el 25 de febrero de 2021.

Díaz-Godoy RV (2007) Caracterización elemental de las partículas suspendidas menores a 2.5 micrómetros y su riesgo a la salud en la zona metropolitana de la Ciudad de México [Tesis de Doctorado, TecNm, Instituto Tecnológico de Toluca]

DOF (2014) NORMA Oficial Mexicana NOM-025-SSA1-2014, Valores límite permisibles para la concentración de partículas suspendidas $\mathrm{PM}_{10}$ y $\mathrm{PM}_{2.5}$ en el aire ambiente y criterios para su evaluación.

https://www.dof.gob.mx/nota detalle.php?codigo=5357042\&fecha=20/08/2014. Consultado el 22 de febrero de 2021

DOF (2021) Ley general del Equilibrio Ecológico y la Protección al Ambiente, Última reforma publicada DOF 18-01-2021. http://www.diputados.gob.mx/LeyesBiblio/pdf/148 180121.pdf. Consultado el 19 de febrero de 2021.

Folkmann F (1975) Analytical use of Ion-Induced X Rays. Journal of Physics E: Scientific Instruments, 8(6) 429. https://doi.org/10.1088/0022-3735/8/6/001

Jhonson RA y Wichern DW (2007) Applied Multivariate Statistical Analysis, 6a ed. Prentice Hall, Inc.

Lenntech (2021) Tabla Periódica. https://www.lenntech.es/periodica/tabla-periodica.htm. Consultado el 25 de febrero de 2021.

Maenhaut W, Fernández-Jiménez, MT, Rajta I y Artaxo P (2002) Two years study of atmospheric aerosols in Alta Floresta, Brazil: Multielemental composition and source apportionment. Volume 189, Issues 1-4, Pages 243-248. https://doi.org/10.1016/S0168-583X(01)01050-3

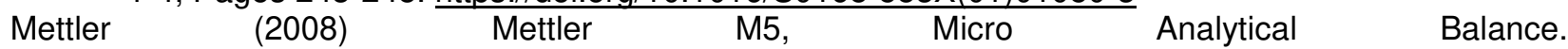
https://www2.humboldt.edu/scimus/Manufac/Mettler/MettlerCat.htm

Montero MÁ, Gracia J, Morell F (2010) Enfermedad pulmonar intersticial por metales duros. Archivos de Bronconeumología, Volume 46, Issue 9, Pages 489-491. https://doi.org/10.1016/i.arbres.2009.10.007.

Núñez YP (2019) Estimación de fuentes de Material Particulado Atmosférico (PM10 y $\left.\mathrm{PM}_{2.5}\right)$ en la Ciudad de Barranquilla Colombia [Tesis de Maestría en Gestión y Sostenibilidad Ambiental, Universidad de la Costa - CUC]. https://repositorio.cuc.edu.co/bitstream/handle/11323/6017/

OMS (2018) Calidad del aire y salud. https://www.who.int/es/news-room/fact-sheets/detail/ambient(outdoor)-air-quality-and-health. Consultado el 25 de febrero de 2021.

Owoade KO, Hopke PK, Olise FS, Ogundele LT, Fawole OG, Olaniyi BH, Jegede OO, Ayoola MA, Bashiru $\mathrm{MI}$ (2015) Chemical compositions and source identification of particulate matter $\left(\mathrm{PM}_{2.5}\right.$ and $\mathrm{PM}_{2.5-}$ 10) from a scrap iron and steel smelting industry along the Ife-lbadan highway, Nigeria, Atmospheric Pollution Research, Volume 6, Issue 1, 2015, Pages 107-119. https://doi.org/10.5094/APR.2015.013 
Peña CE, Carter D E, Ayala-Fierro F (20019) Evaluación de Riesgos y Restauración Ambiental. Distributed on the Internet via the Southwest Hazardous Waste Program website at http://superfund.pharmacy.arizona.edu/toxamb/.

ProAire (2018) Programa de Gestión para Mejorar la Calidad del Aire en el Estado de México. Primera Edición. Número de Dictamen Técnico 214060000/2000/2018. http://proaire.edomex.gob.mx/proaire edomex

RAMA (2021) Red Automática de Monitoreo Atmosférico de la ZMVT. https://rama.edomex.gob.mx/. Consultado el 25 de febrero de 2021.

Rojas CM, Artaxo P, Van-Grieken R (1990) Aerosols in Santiago de Chile: A study using receptor modeling with X-ray fluorescence and single particle analysis. Atmospheric Environment, Volume 24B, Issue 2, Pages 227-241. https://doi.org/10.1016/0957-1272(90)90028-S

SDA (2009) Elementos técnicos del Plan decenal de descontaminación de Bogotá, Parte 1: Caracterización de Material Particulado y Modelos Receptores. Bogotá, D.C., Colombia. ISBN No. 978-958-695-441-9. caracterizacion-pm.pdf

SEMARNAT (2016) Manual para la elaboración de inventarios de fuentes de área. http://dsiappsdev.semarnat.gob.mx/datos/aire/inem/Guias 2016.pdf. Consultado el 20 de febrero de 2021

SMAGEM (2007) Inventario de Emisiones de La Zona Metropolitana del Valle de Toluca, 2004. https://www.yumpu.com/es/document/read/14513663/inventario-de-emisiones-de-lazona-metropolitana-del-valle-de-toluca. Consultado el 20 de febrero de 2021.

SNIARN 12018$) \quad$ Informe del Medio Ambiente.
https://apps1.semarnat.gob.mx:8443/dgeia/informe18/tema/cap5.html. Consultado el 20 de febrero del 2021.

USEPA (1997) Exposure Factors Handbook (1997, Final Report). https://cfpub.epa.gov/ncea/risk/recordisplay.cfm?deid=12464. Consultado el 22 de febrero de 2021.

USEPA (2016) Risk Assessment for Toxic Air Pollutants: A Citizen's Guide. https://www3.epa.gov/airtoxics/3 90 024.html. Consultado el 22 de febrero de 2021

USEPA (2017) IRIS Assessments. https://iris.epa.gov/AtoZ/?list type=alpha. Consultado el 23 de febrero de 2021

USEPA (2020) 40 CFR Appendix L to Part 50 - Reference Method for the Determination of Fine Particulate Matter as $\mathrm{PM}_{2.5}$ in the Atmosphere. https://www.govinfo.gov/content/pkg/CFR2020-title40-vol2/pdf/CFR-2020-title40-vol2-part50-appL.pdf. Consultado el 25 de febrero de 2021

663

664 